\title{
Multiple Introductions of the Pestiferous Land Snail Theba pisana (Müller, 1774) (Gastropoda: Helicidae) in Southern California
}

\author{
Jann E. Vendetti ${ }^{1, *}$, Kimiko Sandig ${ }^{2}$, Armenuhi Sahakyan ${ }^{3}$ and Alyana Granados ${ }^{4}$ \\ 1 Department of Malacology \& Urban Nature Research Center, Natural History Museum of Los Angeles \\ County, 900 Exposition Blvd., Los Angeles, CA 90007, USA \\ 2 Department of Biology, University of California, Santa Barbara, CA 93106, USA; kimisanciara@gmail.com \\ 3 Division of Biological Sciences, University of California, San Diego, CA 92093, USA; asahakyan@ucsd.edu \\ 4 Department of Biology, Williams College, 880 Main St, Williamstown, MA 01267, USA; ajg6@williams.edu \\ * Correspondence: jvendetti@nhm.org
}

Citation: Vendetti, J.E.; Sandig, K.; Sahakyan, A.; Granados, A. Multiple Introductions of the Pestiferous Land Snail Theba pisana (Müller, 1774) (Gastropoda: Helicidae) in Southern California. Insects 2021, 12, 662. https://doi.org/10.3390/insects12080662

Academic Editors: Gordon Port, Jenna Ross and Rory McDonnell

Received: 29 June 2021

Accepted: 13 July 2021

Published: 21 July 2021

Publisher's Note: MDPI stays neutral with regard to jurisdictional claims in published maps and institutional affiliations.

Copyright: (c) 2021 by the authors. Licensee MDPI, Basel, Switzerland. This article is an open access article distributed under the terms and conditions of the Creative Commons Attribution (CC BY) license (https:// creativecommons.org/licenses/by/ $4.0 /)$.
Simple Summary: In Southern California, USA, the introduced white Italian land snail, Theba pisana, is prolific and locally pestiferous. To better understand its diversity and infer its parent population(s), we collected it from Los Angeles and San Diego counties and generated and analyzed gene sequence data (CO1, 16S, ITS2) that we compared between localities and to T. pisana CO1 barcodes from around the world. We also compared the morphology of the jaw, radula, and reproductive systems in T. pisana from Los Angeles and San Diego Counties. We found that T. pisana living at several sites in Los Angeles County in 2019-2020 had a single origin and were most similar in CO1 DNA sequence, based on available data, to specimens from Malta. Theba pisana collected from one site in San Diego County differed from Los Angeles T. pisana and were most similar in CO1 barcode sequence to specimens from Morocco. Jaw and mucous gland morphology also differed between Los Angeles and San Diego populations, but it is unclear if these traits are unique to lineages of T. pisana or if they change during a snail's lifetime. We discuss how Los Angeles and San Diego T. pisana lineages may have arrived in Southern California and anticipate that the genetic data and morphological observations generated by this study will inform future studies of T. pisana where it is native and introduced.

Abstract: The terrestrial land snail Theba pisana is circum-Mediterranean in native range and widely introduced and pestiferous in regions around the world. In California, USA, T. pisana has been recorded intermittently since 1914, but its source population(s) are unknown, and no morphological or molecular analyses within or between California populations have been published. Therefore, we compared molecular data (CO1, 16S, ITS2) and internal morphology (jaw, radula, reproductive system) in T. pisana collected from Los Angeles and San Diego counties in 2019-2020. DNA barcode (CO1 mtDNA) analysis revealed that T. pisana from Los Angeles County was most similar to T. pisana from the Mediterranean island of Malta, and northern San Diego County-collected specimens were most similar to T. pisana from Morocco. Morphology of the jaw and mucous glands also differed between Los Angeles and San Diego populations, but it is unclear if traits are lineage-specific or artifacts of ontogeny. Several pathways of introduction into Southern California are possible for this species, but evidence for intentional vs. accidental introduction of present populations is lacking. Subsequent investigation(s) could use the data generated herein to assess the provenance of T. pisana elsewhere in California and/or worldwide and inform analyses of reproductive biology and systematics in this widespread species.

Keywords: Theba pisana; invasive species; California; provenance; introduced species 


\section{Introduction}

The helicid land snail Theba pisana (Müller, 1774) is remarkable for its colonization of regions far beyond its native coastal Mediterranean and Iberian range [1]. As an introduced species, it is found in coastal Argentina [2], several Atlantic islands [1], Northern and Western Europe (e.g., the U.K. and northern France) [3], South Africa [4,5], the U.S. state of California [6], and Australia [7], where it is pestiferous to several agricultural crops [8]. This wide and disjunct distribution has been mostly passive and human-mediated via vehicles and the transport of goods, freight, agriculture, and horticulture [1,9-11]. In some cases, its introduction may have been intentional [12-14].

In California, USA, T. pisana is mostly found in human-altered habitats in Los Angeles and San Diego counties, where it can aestivate in large numbers on structures and plants $[15,16]$. It was first recorded in California in the community of La Jolla, San Diego County, in 1914 [10,17-19], with several sources claiming it was brought from Southern Europe intentionally as an edible "table delicacy" [12,20]. By the early 1920s, the La Jolla population had grown in density and range, extending more than 20.4 hectares (50 acres) [21,22]. It was considered eradicated by the collective efforts of state, county, and federal agencies via vegetation clearing and burning, molluscicide, and hand-picking [17] However, in 1924, T. pisana was found in a cemetery in southeastern San Diego, and in 1936, it was discovered near La Jolla [23]. In the 1980s, it was detected again in the city of San Diego at two separate localities [6,24,25]; it is not known if snails repopulated from survivors of early eradication efforts or if populations resulted from new introductions.

In Los Angeles and Orange Counties, T. pisana was recorded between 1934 and 1941 [26,27] in Anaheim, Garden Grove, Huntington Beach, Long Beach, Playa del Rey, San Pedro, and Santa Ana $[10,19,28]$. In 1935, the Los Angeles community of southeastern San Pedro had at least three dense populations of T. pisana that extended more than 40.5 hectares (100 acres), which were supposedly eradicated by burning [29]. In 1966, T. pisana was detected in the Los Angeles city of Manhattan Beach [30] and spanned 15 city blocks [31]. It was considered fully eradicated by 1970 after targeted baiting and hand picking [30,32].

Since at least 2013 [33], T. pisana has been documented in Los Angeles County, mostly in San Pedro [15,34,35], and in many sites in San Diego County from the city of Oceanside to the U.S.-Mexico border district of San Ysidro [16]. Notably, through the 2000s, T. pisana was commonly intercepted in cargo (e.g., ceramic tile) and agricultural and horticultural products moving through the ports of Los Angeles, Long Beach, and San Diego [11,36]. The ability of T. pisana to aestivate for long periods without water [19], survive high temperatures, and climb and cling to vertical surfaces [37] allows it to persist in Mediterranean climates worldwide and endure long-distance transport. These abilities and its pestiferous habits, e.g., gregarious massing and herbivory, make it a nuisance species and potentially formidable crop pest [19].

Despite the long history and considerable impact of T. pisana in Southern California, its source population(s) have not been investigated, nor have any differences between disjunct populations been documented. Several studies have used molecular phylogenetic approaches to examine the provenance and source population(s) of T. pisana outside its native range [1,38-40], inferring, for example, a French origin for Australian-living T. pisana [38] and a Dutch origin for South African-living T. pisana [1]. However, none have included California-collected specimens or examined the origins of established populations in Southern California. Therefore, here, we use molecular (mtDNA CO1, 16S rRNA, and ITS2 rDNA) and morphological (reproductive system, radula, and jaw) data to characterize T. pisana from populations in Los Angeles and San Diego County, California, to infer their provenance and document their morphological differences. 


\section{Materials and Methods}

\subsection{Specimen Collection}

Snails fitting the description of T. pisana based on shell color and pattern, size, and aggregating (massing) behavior were collected by hand from plants, structures, and in one case, from a Malaise trap intended for insects as part of the BioSCAN community science project [41]. In Los Angeles County, T. pisana was collected in 2019 and 2020 from San Pedro at multiple sites (Figures 1 and 2, Table 1). In San Diego County, snails were collected in 2020 from a 5 square meter site along Santa Carina trail within the San Elijo Lagoon Ecological Reserve at the border of the communities of Solano Beach and Encinitas (Figures 1 and 2, Table 1). All collected specimens were killed and preserved $24 \mathrm{~h}$ after collection and deposited in the Natural History Museum of Los Angeles County's (NHMLAC) Malacology Collection, with lot numbers preceded by LACM (Los Angeles County Museum) (Table 1). For clarity and brevity, T. pisana specimens will be referred to as "San Pedro" for those collected from San Pedro in Los Angeles County and "San Elijo" for those collected from the San Elijo Lagoon Ecological Reserve in San Diego County.

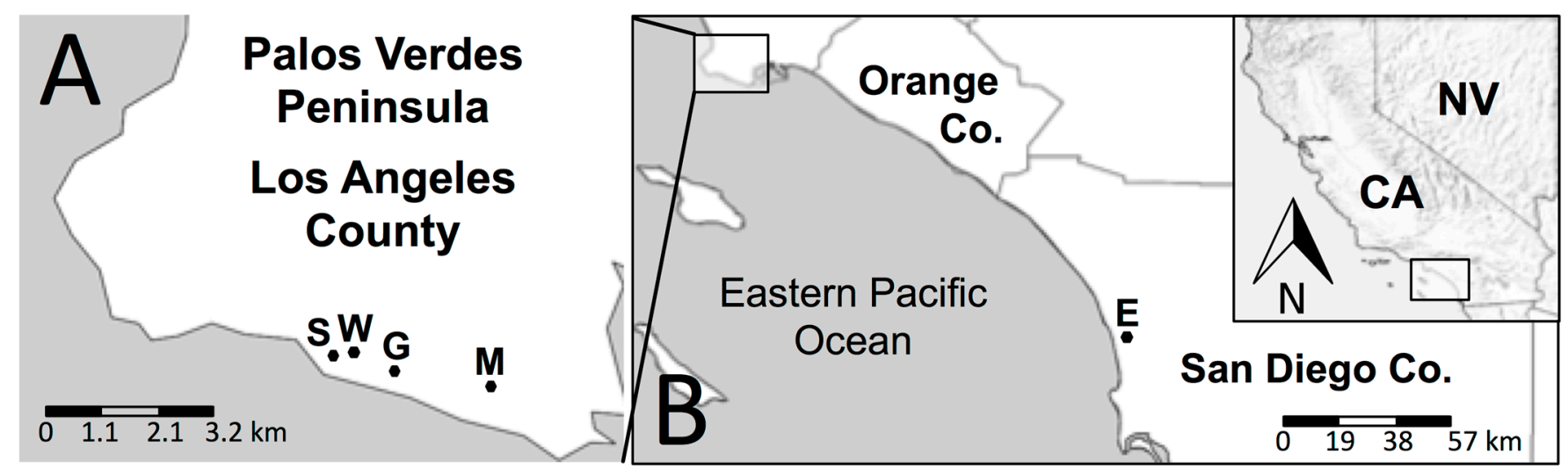

Figure 1. The collection sites for Theba pisana (Müller, 1774) in Los Angeles and San Diego Counties, California, USA. (A) map of the Palos Verdes Peninsula, Los Angeles Co., S: south entrance of White Point Nature Preserve (WPNP), San Pedro; W: native plant garden, WPNP, San Pedro; G: grassland loop trail of WPNP, San Pedro; M: Marine Mammal Care Center, San Pedro; (B) map of southwestern Los Angeles Co. to San Diego Co., California (CA), NV: Nevada, USA; E: Santa Carina trail at San Elijo Lagoon Ecological Reserve, San Diego County.

\subsection{Specimen Preparation and Morphological Examination}

Snails were killed by immersion in carbonated water for $2-4 \mathrm{~h}$, then transferred to and stored in $95 \%$ ethanol (EtOH). Dissections under optical microscopy were performed using a Wild Heerbrugg M5A (Switzerland) or Nikon SMZ1000 (Japan) stereomicroscope. Reproductive anatomy was examined by opening each snail's body near its genital pore and removing its reproductive system. Terminology of reproductive parts follows Gittenberger and Ripken [3], Moran [42], Koene and Schulenburg [43], and Holyoak and Holyoak [44].

Shells and reproductive anatomy were photographed with a Nikon D7200 digital SLR camera using a macro lens. The degree of maturation of reproductive parts was determined by comparing San Pedro specimens collected in June of 2019, June 2020, and October 2020, and San Elijo snails collected in September of 2020. The size of snails' paired mucous glands (also known as glandulae mucosae) was used to categorize reproductive systems as immature, intermediate, or mature in 5-15 dissected specimens per site (Table 1). Reproductive maturity categories were informed by Moran [42] and were as follows: (1) immature: mucous glands approximately $1 \mathrm{~mm}$ long, thin, and rudimentary similar to the rest of the reproductive system; (2) intermediate: mucous glands approximately $5 \mathrm{~mm}$ long and $1 \mathrm{~mm}$ thick at mid-length; (3) mature: mucous glands $13-16 \mathrm{~mm}$ long and $2 \mathrm{~mm}$ at mid-length. 
Table 1. Data for Theba pisana (Müller, 1774) specimens collected from Los Angeles and San Diego counties, California, USA and used in this study.

\begin{tabular}{|c|c|c|c|c|c|c|c|c|}
\hline \multirow{2}{*}{$\begin{array}{l}\text { LACM Lot } \\
\text { Number }\end{array}$} & \multirow{2}{*}{$\begin{array}{l}\text { Collection } \\
\text { Date }\end{array}$} & \multirow{2}{*}{$\begin{array}{l}\text { Isolate } \\
\text { Name }\end{array}$} & \multicolumn{3}{|c|}{ GenBank Accession Number } & \multirow{2}{*}{$\begin{array}{l}\text { Reproductive } \\
\text { System }\end{array}$} & \multirow{2}{*}{\multicolumn{2}{|c|}{ Collection Locality }} \\
\hline & & & CO1 & ITS2 & $16 S$ & & & \\
\hline \multirow{5}{*}{182358} & \multirow{5}{*}{ 1-Jun-2019 } & ThbaS36A & MW831635 & MW832220 & MW847212 & \multirow{5}{*}{$\begin{array}{c}100 \% \\
\text { Immature } \\
(n=5)\end{array}$} & \multirow{18}{*}{ 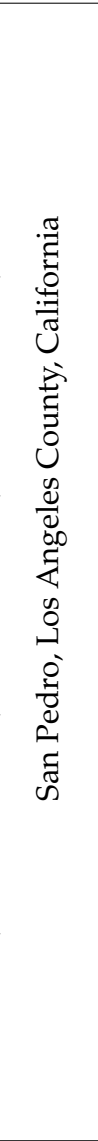 } & \multirow{9}{*}{$\begin{array}{c}\text { Marine Mammal Care } \\
\text { Center, } \\
33.712,-118.295\end{array}$} \\
\hline & & ThbaSS36B & MW831647 & MW832226 & MW847224 & & & \\
\hline & & ThbaSS36C & MW831648 & MW832227 & MW847225 & & & \\
\hline & & ThbaAS36A & MW831640 & MW832224 & MW847217 & & & \\
\hline & & ThbaAS36B & MW831641 & MW832225 & MW847218 & & & \\
\hline \multirow{4}{*}{182330} & \multirow{4}{*}{ 22-Jun-2020 } & ThbaJV22A & MW831636 & MW832221 & MW847213 & \multirow{4}{*}{$\begin{array}{c}100 \% \\
\text { Immature } \\
(n=15)\end{array}$} & & \\
\hline & & ThbaJV22B & MW831637 & MW832222 & MW847214 & & & \\
\hline & & ThbaJV22C & MW831638 & MW832223 & MW847215 & & & \\
\hline & & ThbaJV22D & MW831639 & - & MW847216 & & & \\
\hline \multirow{4}{*}{182329} & \multirow{4}{*}{ 22-Jun-2020 } & ThbaJV22E & MW831642 & - & MW847219 & \multirow{4}{*}{$\begin{array}{c}100 \% \\
\text { Immature } \\
(n=15)\end{array}$} & & \multirow{4}{*}{$\begin{array}{c}\text { White Point } \\
\text { Nature Preserve, } \\
\text { south entrance, } \\
33.716,-118.316\end{array}$} \\
\hline & & ThbaJV22F & MW831643 & - & MW847220 & & & \\
\hline & & ThbaJV22G & MW831644 & - & MW847221 & & & \\
\hline & & ThbaJV22H & MW831645 & - & MW847222 & & & \\
\hline \multirow{4}{*}{182331} & \multirow{4}{*}{ 22-Jun-2020 } & ThbaJV22I & MW831651 & - & MW847228 & \multirow{4}{*}{$\begin{array}{c}100 \% \\
\text { Immature } \\
(n=15)\end{array}$} & & \multirow{4}{*}{$\begin{array}{l}\text { White Point } \\
\text { Nature Preserve, } \\
\text { native plant } \\
\text { garden, } \\
33.716,-118.315\end{array}$} \\
\hline & & ThbaJV22J & MW831646 & - & MW847223 & & & \\
\hline & & ThbaJV22K & MW831650 & - & MW847227 & & & \\
\hline & & ThbaJV22L & MW831649 & - & MW847226 & & & \\
\hline 182342 & 17-Oct-2020 & - & - & - & - & $\begin{array}{c}7 \% \\
\text { Immature } \\
93 \% \\
\text { Mature } \\
(n=15)\end{array}$ & & $\begin{array}{c}\text { White Point } \\
\text { Nature Preserve, } \\
\text { grassland loop trail, } \\
33.715,-118.311\end{array}$ \\
\hline \multirow{10}{*}{182335} & \multirow{10}{*}{ 12-Sept-2020 } & ThbaJV12A & MW831652 & MW832228 & - & \multirow{10}{*}{$\begin{array}{c}20 \% \\
\text { Immature } \\
80 \% \\
\text { Intermediate? } \\
\quad(n=15)\end{array}$} & \multirow{10}{*}{ 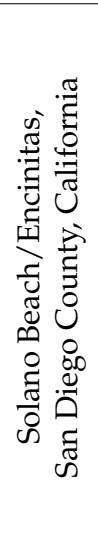 } & \multirow{10}{*}{$\begin{array}{l}\text { San Elijo Lagoon } \\
\text { Ecological } \\
\text { Reserve, } \\
\text { Santa Carina trail, } \\
33.0077,-117.2596\end{array}$} \\
\hline & & ThbaJV12B & MW831654 & MW832230 & - & & & \\
\hline & & ThbaJV12C & MW831655 & MW832231 & - & & & \\
\hline & & ThbaJV12D & MW831656 & MW832232 & - & & & \\
\hline & & ThbaJV12E & MW831657 & MW832233 & - & & & \\
\hline & & ThbaJV12F & MW831658 & MW832234 & - & & & \\
\hline & & ThbaJV12G & MW831659 & - & - & & & \\
\hline & & ThbaJV12H & MW831660 & MW832235 & - & & & \\
\hline & & ThbaJV12I & MW831653 & MW832229 & - & & & \\
\hline & & ThbaJV12J & MW831661 & - & - & & & \\
\hline
\end{tabular}




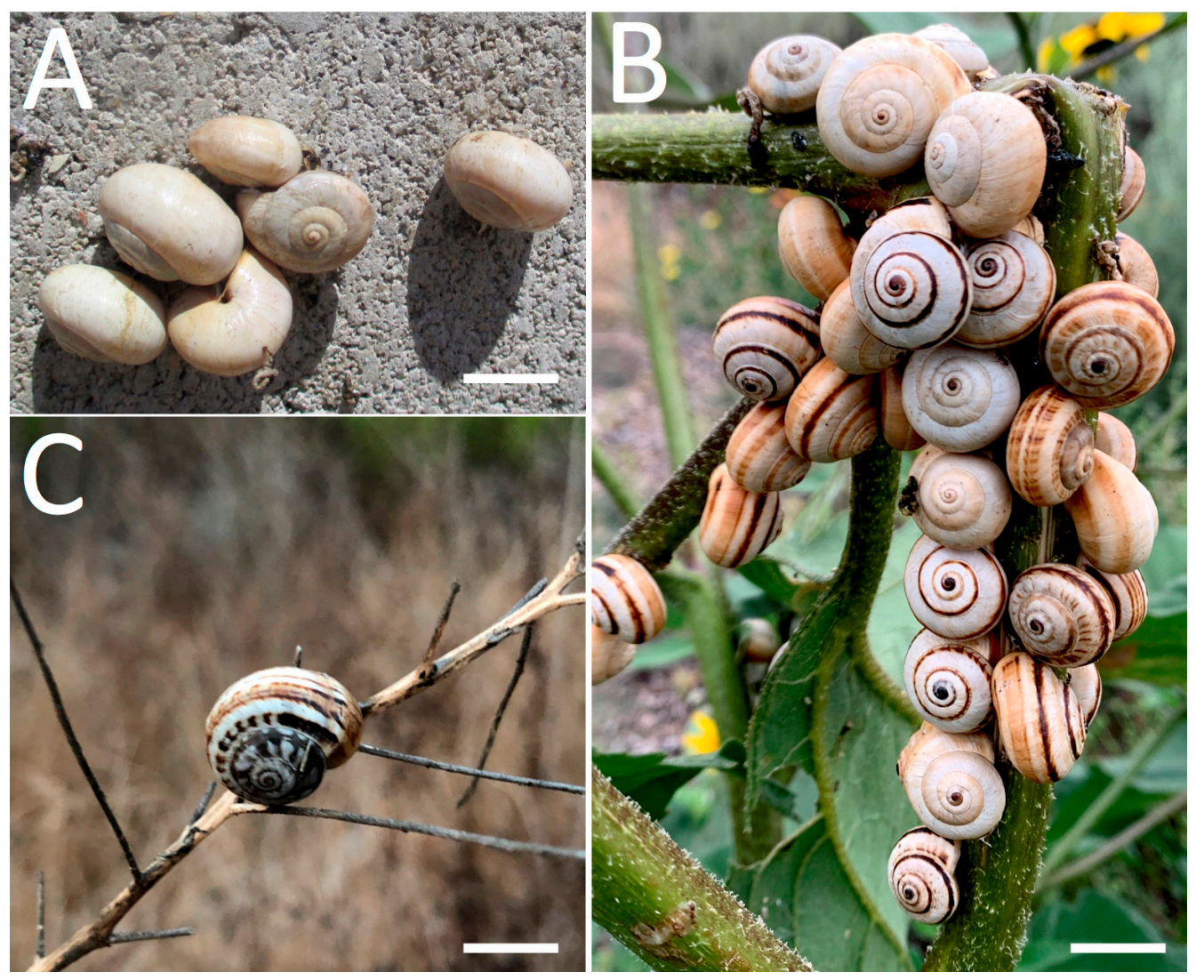

Figure 2. Aestivating Theba pisana (Müller, 1774) from sites in Los Angeles and San Diego Counties, California, USA. (A) Outside the Marine Mammal Care Center, San Pedro, Los Angeles Co.; (B) within the native plant garden of White Point Nature Preserve, San Pedro, Los Angeles Co.; (C) along Santa Carina trail, San Elijo Lagoon Ecological Reserve, San Diego Co. Scale bar is $1 \mathrm{~cm}$. Photos A and C by J. Vendetti; photo B by M. Connolly.

Specimens from which radulae and jaws were excised and examined were of typical adult shell size $(1.3-1.4 \mathrm{~cm})$ regardless of collection locality. To prepare for scanning electron microscopy (SEM), the buccal mass containing a single jaw and radula was removed from each specimen, immersed in $5 \mathrm{M} \mathrm{NaOH}$ for 1 to $6 \mathrm{~h}$ to dissolve adhering tissue, then cleaned using insect pins and/or fine forceps in several washes of $95 \%$ ethanol and water. Clean jaws and radulae were then mounted on metal disks with carbon conductive tape, coated with gold/palladium (60:40) at $0.014 \mathrm{k} \AA$ by an Emitech K550x sputter coater (Kent, United Kingdom), and digitally imaged using a Hitachi S-3000N SEM (Tokyo, Japan) in the SEM laboratory at NHMLAC. Digital image backgrounds were removed in PowerPoint (Microsoft), and image contrast and brightness were adjusted in Preview v. 8.0 in MacOS X. Measurements of jaw width (jw) and jaw ridge length (rl) were made directly from SEM images using its scale bar. Jaw ridge length was calculated as the mean of the two most prominent ridges in each jaw. Jaw width was measured as the length between the middle points of each jaw tip or end.

\subsection{Generation of Sequence Data}

Total DNA was extracted from foot tissue clippings of EtOH-preserved T. pisana specimens using the Qiagen DNeasy ${ }^{\circledR}$ Blood and Tissue Kit (Qiagen Corp; Valencia, CA, USA) following the manufacturer's instructions. Amplification by polymerase chain reaction (PCR) used the following primer pairs: the barcode portion of mtDNA cytochrome c oxidase subunit 1 (CO1): LCO1490 and HCO2198 [45] and jgLCO1490 and jgHCO2198 [46] ( $n=27,17$ San Pedro and 10 San Elijo), 16S rRNA: 16Sar-L and 16Sbr-H [47] ( $n=17$, only San Pedro), and ITS2 rDNA: LSU-1F and LSU-3R [48] ( $n=16,8$ San Pedro and 8 San Elijo). 
Protocols for PCR amplification follow Vendetti et al. [49]. PCR products were purified then sequenced in both directions using PCR primers by Retrogen, Inc. (San Diego, CA, USA). Sequences were visualized as chromatograms and aligned and trimmed of primers in Geneious v. 8.1.6 [50] to a total sequence length of 655 base pairs (bp) for CO1, 402-403 bp for $16 \mathrm{~S}$, and $830-835 \mathrm{bp}$ for ITS2. All sequences were submitted to GenBank with the following accession numbers: CO1: MW831635-MW831661, 16S: MW847212-MW847228, and ITS2: MW832220-MW832235. Additional collection details are in Table 1.

\subsection{Sequence Comparison, Analysis, and Phylogenetic Inference}

CO1 barcodes generated for this study were compared to Theba taxa within the NCBI GenBank and Barcode of Life (BOLD) databases and were identified therein as T. pisana, T. pisana pisana (e.g., GenBank acc. nos. HQ864655-HQ864657), T. p. ampullacea (e.g., GenBank acc. nos. HM034564-HM034566) and T. p. cantinensis (e.g., GenBank acc. no. HM034569). These sequences have been published elsewhere $[2,39,40,51]$ and represent a broad sample of T. pisana where native (e.g., Spain, Morocco) and introduced (e.g., South Africa and Australia). Partial CO1 sequences were collapsed into haplotypes using the web interface of FaBox's DNAcollapser [52]. Genetic distances for CO1 haplotypes were calculated in MEGA7 [53] using the Kimura 2-parameter model (K2P) for nucleotide alignments (using all codon positions).

Mitochondrial CO1 and 16S sequences were concatenated in Geneious v. 6.1.6 and v. 8.1.6 using Geneious Alignment, Consensus Alignment, MUSCLE with default parameters, and the concatenation function. Akaike information criterion (AIC) was used to evaluate the best-fitting model of sequence evolution for CO1, 16S, and ITS2 within jModelTest2 [54] or ModelTest-NG [55] on XSEDE within the CIPRES Science Gateway 3.3 [56]. The outgroup for the concatenated mtDNA CO1 and $16 \mathrm{~S}$ alignment and analysis was Theba subdentata, GenBank acc. nos. MF564172 (CO1) and MF564126 (16S) [57]; for ITS2 it was also T. subdentata, GenBank acc. no. KJ458640 [58], in a dataset that also included T. pisana, GenBank acc. no. KR705081 [59]. To visualize the relationships among CO1, 16S, and ITS2 sequences, median-joining [60] haplotype networks were created in PopART (Population Analysis with Reticulate Trees) 1.7 [61] using an epsilon value of zero.

Phylogenies were generated in RAxML v. 8.2.12 [62] and MrBayes 3.2.7a [63] within the CIPRES Science Gateway 3.3 [56]. RAxML analyses were run using RAxML-HPC BlackBox with default parameters. Bootstrap values were halted by RAxML automatically after 504-1000 replicates using an MRE-based bootstrapping criterion [64]. MrBayes Bayesian Inference analyses were parameterized to produce a $50 \%$ majority consensus tree from two runs of four Markov chains, each of 30 million generations, using the best fitting model of sequence evolution, partitioned with concatenated data, sampling every 1000 trees, and with a discarded burn-in fraction of $25 \%$. For CO1, a second MrBayes analysis was run with the same parameters as described above to account for potential saturation of the third codon position [39]. The resulting phylogenies were visualized using FigTree v. 1.4.3 [65]. Nodes were labeled with maximum likelihood (RAxML) bootstrap support values $\geq 75$, followed by Bayesian posterior probabilities $\geq 0.90$.

\section{Results}

\subsection{Shell Morphology}

Theba pisana shells from San Pedro and San Elijo all were of non-glossy texture, had fine growth lines, an umbilicus partially covered by the body whorl, and lacked a keel or thickened apertural lip. Protoconchs were yellow/white, dark brown, or blue/black. Color and pattern were variable; shells were partially to entirely light yellow to an off-white shade similar to the ground color with a pattern, if present, of light to dark brown stripes, chevrons, and/or mottled or dotted bands (Figures 2 and 3). Characterization of banding (or lack thereof), as well as variation within and between collection sites, was not analyzed quantitatively; however, San Pedro specimens collected near the Marine Mammal Care 
Center had white to yellow shells with no banding, unlike the mostly patterned and banded shells at all other localities (Figure 3).

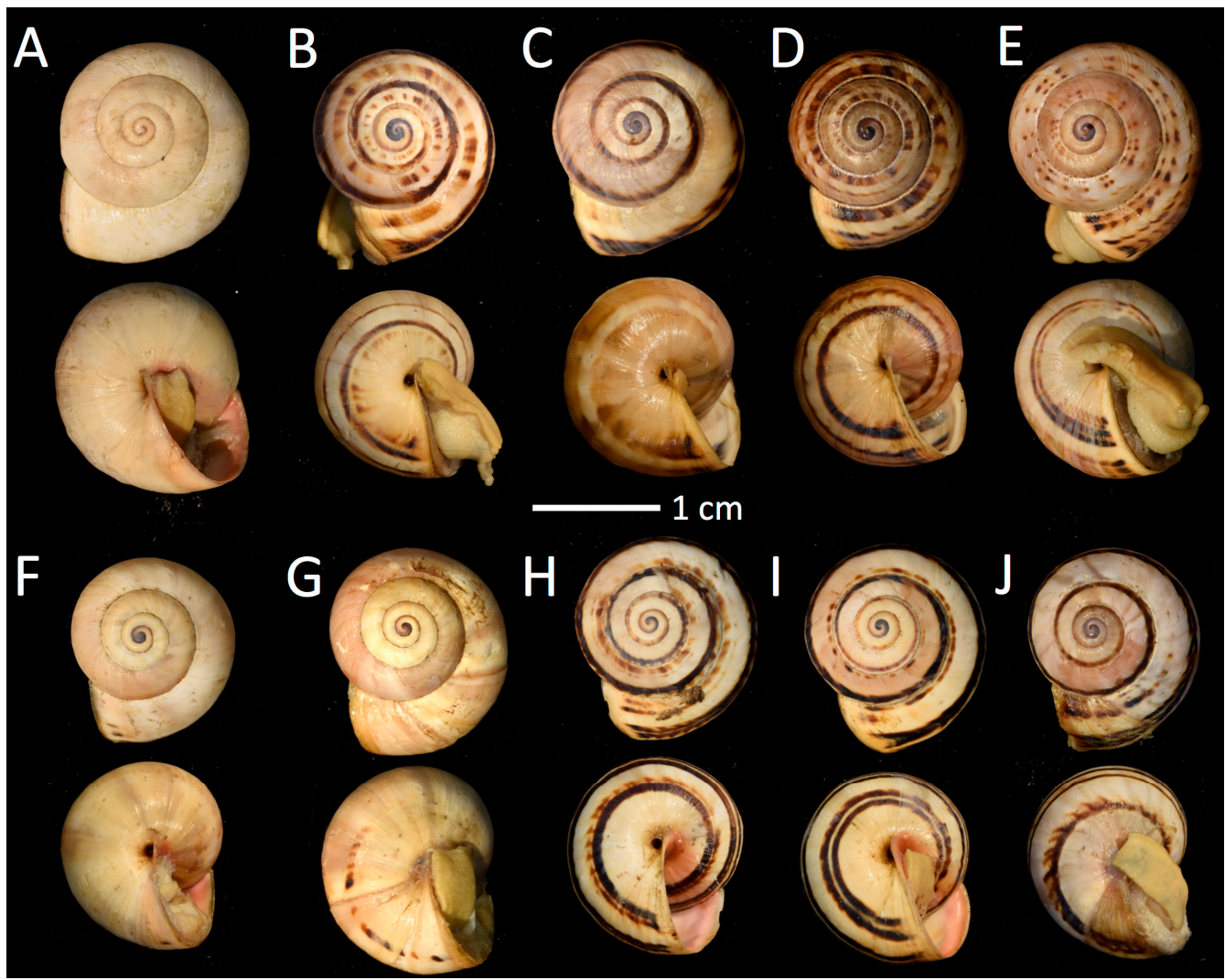

Figure 3. Apical and umbilical view of Theba pisana (Müller, 1774) collected in San Pedro, Los Angeles Co. (A-E) and San Elijo Lagoon Ecological Reserve, San Diego Co. (F-J), California, USA. (A) from outside the Marine Mammal Care Center, LACM 182330; (B-E) White Point Nature Preserve, LACM 182331; (F-J) from Santa Carina trail at San Elijo, LACM 182335.

\subsection{Radular Morphology}

Theba pisana radular morphology examined and figured herein (Figure 4) is consistent with illustrations by Hesse [66] and Barker and Efford [67] and did not differ between San Pedro and San Elijo populations. Tooth size did not differ significantly within or between San Pedro and San Elijo populations: San Pedro central tooth $(n=5)$, length: $\mathrm{M}=26.8 \mu \mathrm{m}, \mathrm{SD}=2.05 \mu \mathrm{m}$; width: $\mathrm{M}=16.40 \mu \mathrm{m}, \mathrm{SD}=0.55 \mu \mathrm{m}$; San Elijo central tooth $(n=5)$, length: $\mathrm{M}=25.6 \mu \mathrm{m}, \mathrm{SD}=0.55 \mu \mathrm{m}$; width: $\mathrm{M}=15.60 \mu \mathrm{m}, \mathrm{SD}=0.89 \mu \mathrm{m}$. Mature central teeth were symmetrical, tricuspid, and lanceolate with pointed lateral cones and mesocones of a slightly ovate shape that was half the length of the total tooth. The tooth base was an equilateral or isosceles triangle from the tips of the central tooth's lateral cones to just beyond the tip of the mesocone. Lateral teeth were bicuspid, pointed, and ovate, with a well-developed ectocone half the length of the total tooth. Teeth became lanceolate with a very small endocone that appeared as a bump or tiny point the closer the lateral teeth were to marginal teeth. Marginal teeth were somewhat variable, with a pointed mesocone next to an endocone that could equal it in size, such that the mesocone appeared bicuspid; the ectocone was shorter than the endocone, pointed, and separated from the mesocone by a v-shaped indentation. 


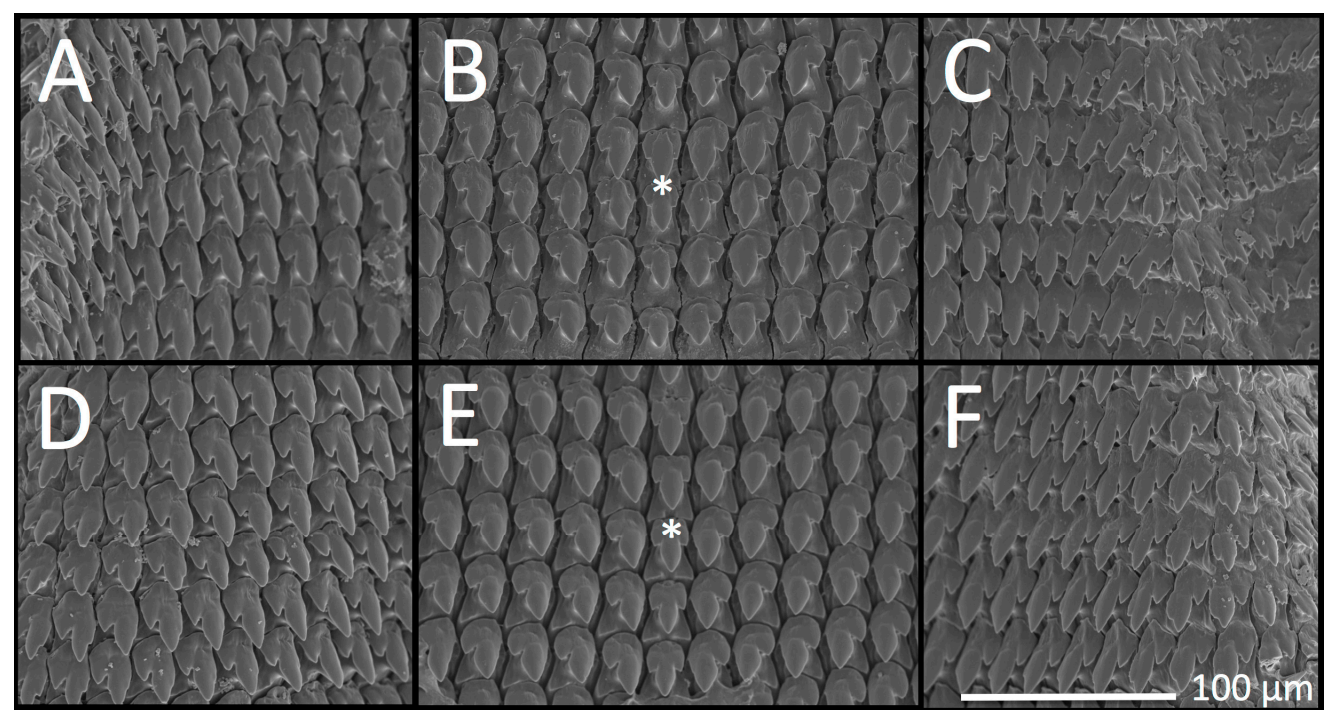

Figure 4. Theba pisana (Müller, 1774) radulae as SEM images from specimens collected in San Pedro, Los Angeles Co. (A-C) and San Elijo Lagoon Ecological Reserve, San Diego Co., California, USA (D-F). (A-C) from outside the Marine Mammal Care Center, LACM 182330; (A,C) lateral and marginal teeth; (B) central and lateral teeth; (D-F) from Santa Carina trail, LACM 182335; (D,F) lateral and marginal teeth; (E) central and lateral teeth. Asterisks indicate a central tooth within the central vertical tooth row.

\subsection{Reproductive Anatomy}

Three putative stages of maturation in reproductive anatomy (e.g., immature, intermediate, and mature) were observed in collected T. pisana (Table 1, Figure 5). All examined San Pedro specimens collected in June 2019 and June 2020 were reproductively immature (LACM 182329, 182330, 182331, 182358, $n=50$ ), September 2020-collected San Elijo T. pisana were $20 \%$ immature and $80 \%$ intermediate (LACM 182335, $n=15$ ), and October 2020-collected T. pisana from White Point Nature Preserve were 7\% intermediate and 93\% mature (LACM 182342, $n=15$ ). In San Pedro in 2020, the 117 days between collecting events in summer (22 June) and fall (17 October) was sufficient time for most snails' reproductive systems to mature. However, because specimens were collected only once in San Elijo (in September) and had what we speculate to be mostly intermediate reproductive systems, we do not know their maturation rate or timeline of reproductive maturity. Notably, mucous gland morphology was different between Los Angeles and San Diego sites, with San Pedro specimens having single-lobed mucous glands in October and San Elijo specimens having bi-lobed mucous glands in September. 


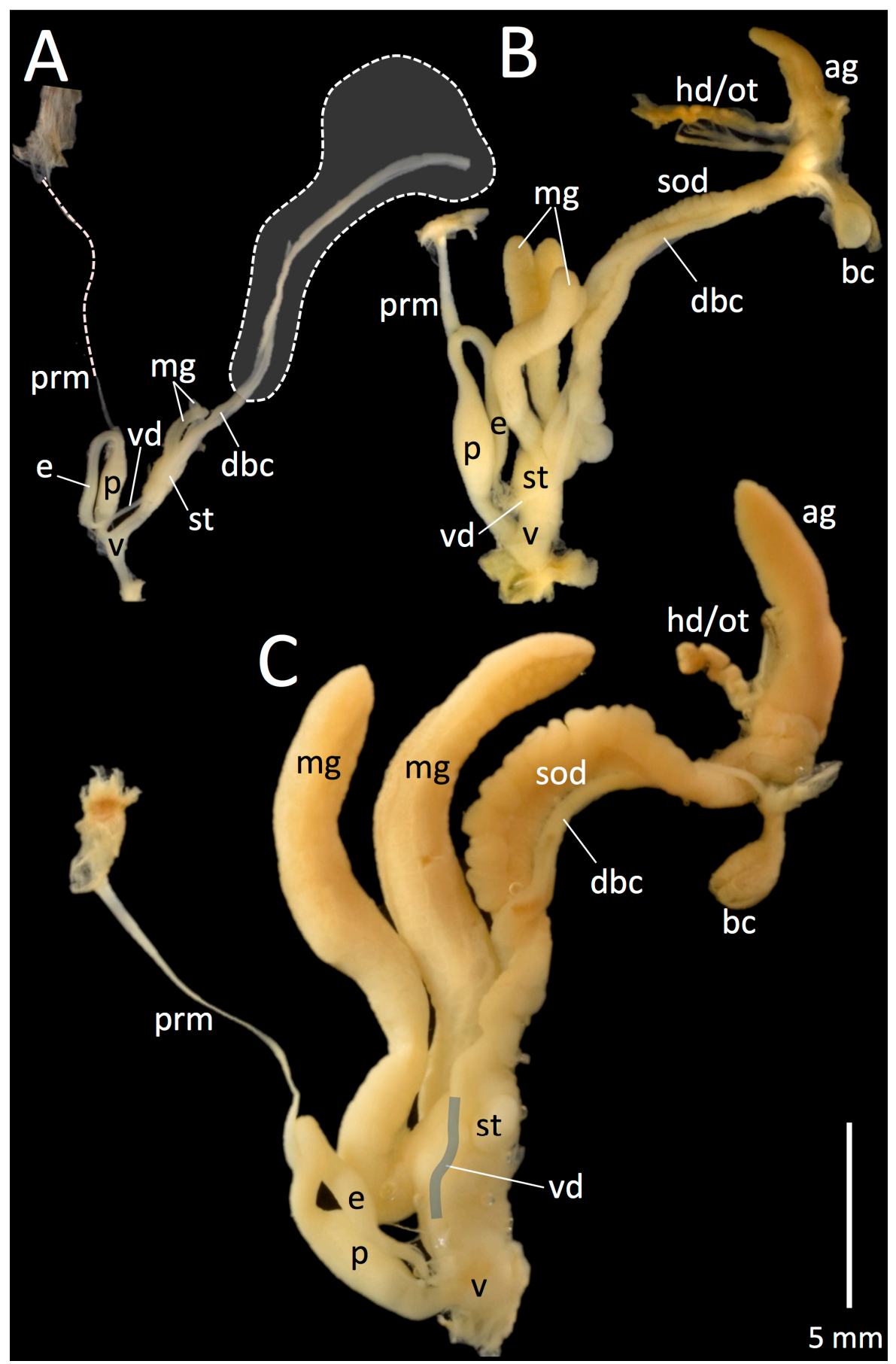

Figure 5. Theba pisana (Müller, 1774) reproductive systems at different stages of maturity from San Pedro, Los Angeles Co. (A,C) and San Elijo Lagoon Ecological Reserve, San Diego Co., California, USA (B). (A) LACM 182330 (immature), Marine Mammal Care Center, 22 June 2020; (B) LACM 182335 (immature?), Santa Carina trail, 12 September 2020; (C) LACM 182342 (mature), Grassland Loop Trail, White Point Nature Reserve, 17 October 2020. Abbreviations: ag: albumen gland; bc: bursa copulatrix; dbc: duct of bursa copulatrix; e: epiphallus; hd/ot: hermaphroditic duct/ovotestis; mg: mucous gland; p: phallus; prm: phallus retractor muscle; sod: spermoviduct; st: stylophore (dart sac); vd: vas deferens; v: vagina. In (A), the single dashed line indicates part of the phallus retractor muscle; the gray area within the dashed line indicates missing anatomy, including the sod, bc, ag, and hd/ot; in (C), the vas deferens is indicated in gray. Anatomical terminology is based on Koene and Schulenburg [43] and Holyoak and Holyoak [44]. Figure layout is based on Moran [42]. 


\subsection{Jaw Morphology}

Jaws were dark orange to reddish-brown in color, crescent or horseshoe-shaped, and odontognathic with very fine and closely spaced striations and 2-3 medially positioned ridges or ribs of varying prominence and spacing (Figure 6). In all specimens examined, at least two ridges protruded beyond the lower edge of the jaw. Jaw morphology of San Pedro (Figure 6A-I) and San Elijo (Figure 6J-N) specimens appeared to be different; jaw ridges were more prominent and in greater relief in San Elijo specimens than in San Pedro specimens. Ridges in the jaws from five out of five San Elijo specimens were of equal or nearly equal size, and jaws had no minor or less prominent ridges, whereas, in nine out of ten San Pedro specimens, jaws had a less prominent ridge (with specimen $\mathrm{H}$ as the exception, Figure $6 \mathrm{H}$ ). Mean (M) jaw ridge length and mean jaw width differed between San Pedro and San Elijo T. pisana, but not significantly: San Pedro jaw width: $n=10, \mathrm{M}=1.34 \mathrm{~cm}, \mathrm{SD}=0.19 \mathrm{~cm}$; jaw ridge length: $n=10, \mathrm{M}=0.62 \mathrm{~cm}, \mathrm{SD}=0.04 \mathrm{~cm}$; San Elijo jaw width: $n=5, \mathrm{M}=1.17 \mathrm{~cm}, \mathrm{SD}=0.12 \mathrm{~cm}$; jaw ridge length: $n=5, \mathrm{M}=0.69 \mathrm{~cm}$, $\mathrm{SD}=0.09 \mathrm{~cm}$. Jaw ridge prominence, measured as the ratio of jaw ridge length (the mean of the two most prominent ridges in each jaw) to jaw width (the length between the middle points of each end or tip of the jaw's horseshoe shape), was significantly different between San Pedro and San Elijo T. pisana according to a Welch's $t$-test, $t(5.18)=-2.69, p<0.04$.

\subsection{Molecular Sequence Data and Phylogenetic Systematics}

San Pedro T. pisana 16S haplotypes differ by only 1-2 bp (Figure 7A), and CO1 haplotypes differ by $4 \mathrm{bp}$. In the CO1 and $16 \mathrm{~S}$ concatenated dataset of San Pedro T. pisana (Figure 7B), haplotypes form three clades, the largest of which is reflected in the 16S haplotype network (Figure 7A) and includes specimens from sites within the White Point Nature Preserve but not from the site near the Marine Mammal Care Center (Table 1). Mean intraspecific K2P genetic distance within San Pedro and San Elijo T. pisana CO1 haplotypes was $0.4 \%$; between San Pedro and San Elijo populations, it was 13\% (Table 2). Between San Pedro and San Elijo T. pisana CO1 haplotypes, there were 79 bp differences. Models of sequence evolution for phylogenetic analyses herein were GTR + I + gamma for CO1, K80 for 16S, and TPM1uf for ITS2.

In ITS2 sequence data, phylogenetic analysis resolved Los Angeles and San Diego T. pisana as monophyletic, with 82 and 94 bootstrap support, respectively (Figure 7C). ITS2 sequences differed between San Pedro $(n=8)$ and San Elijo $(n=8)$ T. pisana specimens by $2 \mathrm{bp}$ (Figure 7D).

The most common CO1 haplotype from 17 San Pedro T. pisana specimens was found in 9 specimens collected near the south entrance of White Point Nature Preserve (WPNP) (BioSCAN 2019 and 2020 sites) and the White Point native plant garden; another haplotype was shared by specimens from the BioSCAN WPNP site and Marine Mammal Care Center site (Figure 8A). Two CO1 haplotypes were found among the 10 San Elijo-collected T. pisana specimens (Figure 8B).

Phylogenetic analyses of T. pisana CO1 haplotypes from San Pedro, San Elijo, and localities worldwide indicate T. pisana from sites in Los Angeles as most similar to specimens collected in Malta (e.g., GenBank acc. nos. HQ864655-56 [1], HM034577 [39], and KF582651 [40]) (Figure 8C and Supplementary Figure S1A), and San Elijo T. pisana as most similar to specimens collected in Morocco (e.g., GenBank acc. nos. HM034558-59, HM034561-63 [39], KF582658 [40]) (Figure 8C and Supplementary Figure S1B). Clades within this phylogeny (Figure 8C) also indicate affinities between T. pisana populations elsewhere in the world, e.g., South Africa and Southeast Australia, and the Canary Islands, France, Cyprus, and Morocco. Phylogenies have been uploaded to TreeBase at the following url: http:/ / purl.org/phylo/treebase/phylows/study/TB2:S28531 (12 July 2021). 


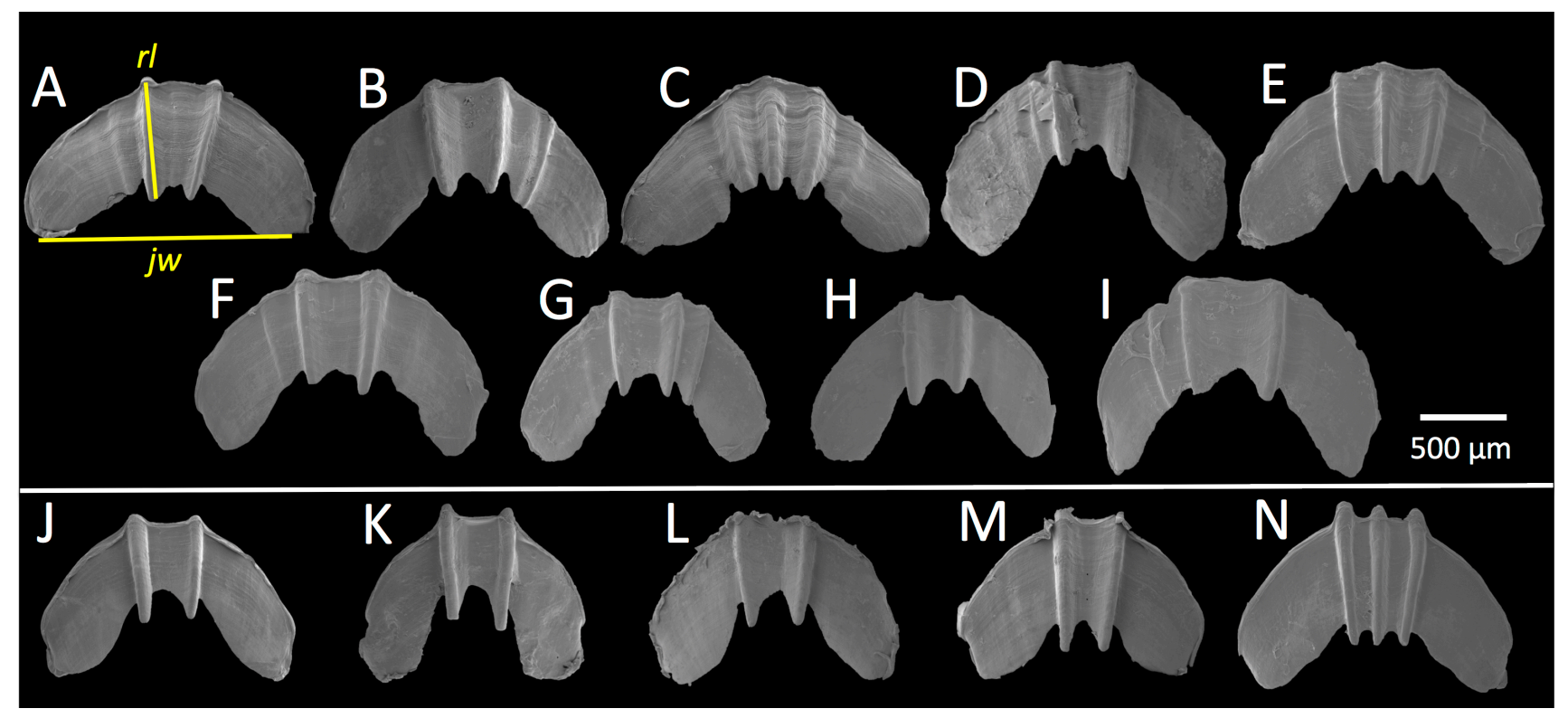

Figure 6. Theba pisana (Müller, 1774) jaws as SEM images from specimens collected in San Pedro, Los Angeles Co. (A-I) and San Elijo Lagoon Ecological Reserve, San Diego Co. (J-N), California, USA. (A-B) From the south entrance of White Point Nature Preserve, 22 June 2020, LACM 182329; (C) from outside the Marine Mammal Care Center, 22 June 2020, LACM 182330; (D-I) from White Point Nature Preserve, 17 October 2020, LACM 182342; and (J-N) from San Elijo Lagoon Ecological Reserve, 12 September 2020, (J) LACM 182335, (K-N) LACM 182334. Measurements of jaw width (jw) and jaw ridge length $(\mathrm{rl})$ are indicated in $(\mathbf{A})$.

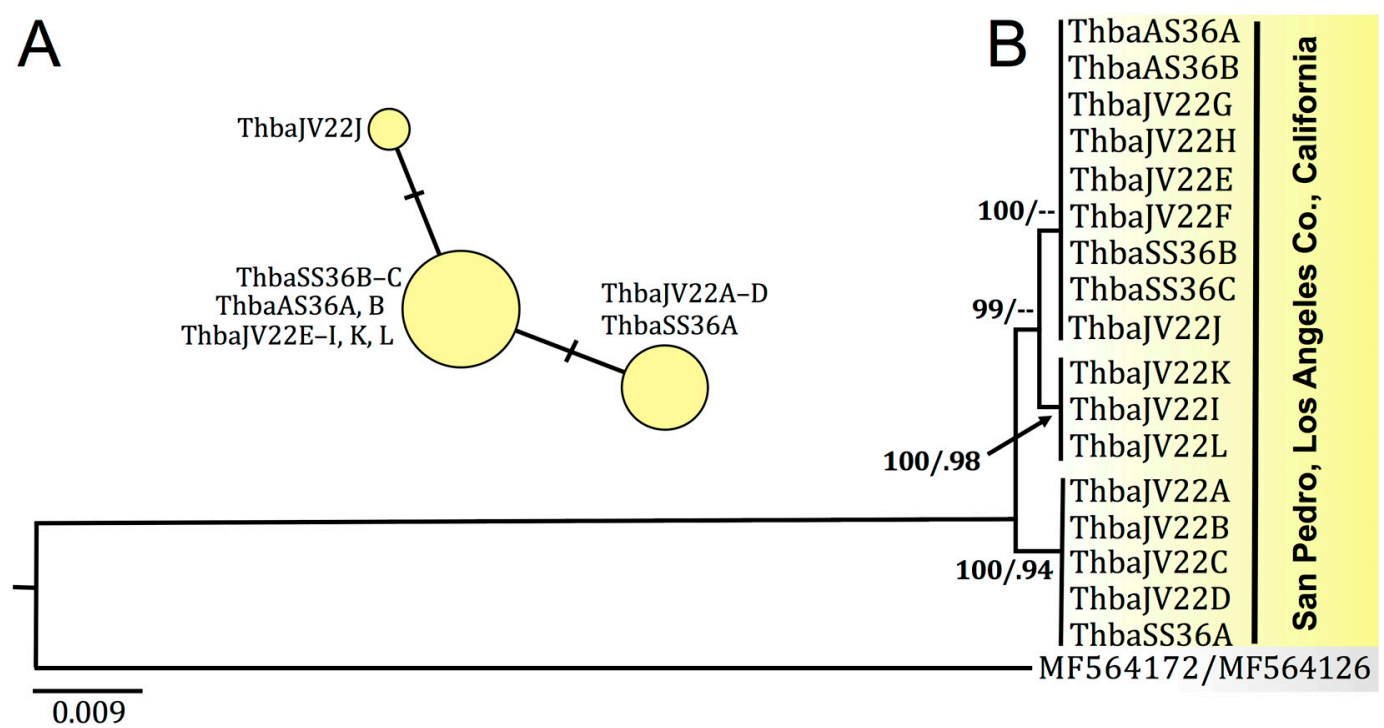

Figure 7. Cont. 


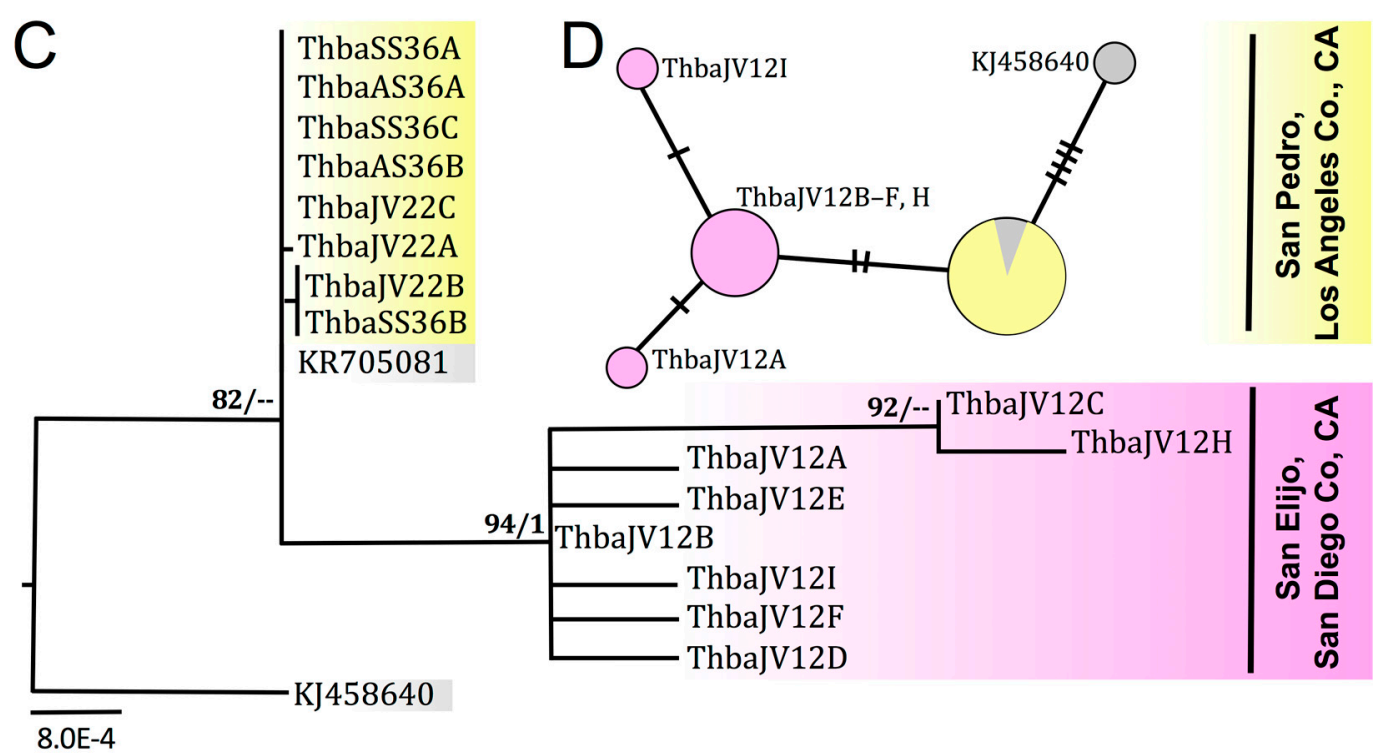

Figure 7. Haplotype networks and RAxML maximum likelihood phylogenies of Theba pisana mtDNA CO1 and $16 \mathrm{~S}$ haplotypes and ITS2 sequences. (A) Median-joining 16S rRNA network of 17 T. pisana haplotypes from specimens collected in San Pedro, Los Angeles County, California, USA, (B) RAxML phylogeny based on concatenated mtDNA CO1 and 16S rRNA sequence data (1059 bp) from specimens collected in San Pedro, Los Angeles County, California (in yellow) with the outgroup Theba subdentata, GenBank acc. nos. MF564172 (CO1) and MF564126 (16S), from Souss-Massa, Morocco [57], (C) RAxML phylogeny based on partial ITS2 sequence data (836 bp) from specimens collected in San Pedro, Los Angeles County, California (in yellow) and San Elijo Lagoon Ecological Reserve, San Diego County, California (in pink) with T. pisana, GenBank acc. no. KR705081, from Tenerife, Canary Islands [59] and the outgroup Theba subdentata, GenBank acc. no. KJ458640, from Almería, Spain [58]; (D) Median-joining ITS2 network of 16 T. pisana sequences from San Pedro, Los Angeles County, California (in yellow) and San Elijo Lagoon Ecological Reserve, San Diego County, California (in pink) with T. pisana (KR705081) and T. subdentata (KJ458640) as in (C). In phylogenies, RAxML bootstrap support values $\geq 75$ are followed by Bayesian posterior probabilities $\geq 0.90$. In haplotype networks, circle size is proportional to the number of haplotypes in the dataset, and each hashmark represents a single nucleotide difference between haplotypes. For GenBank accession numbers, see Table 1.

Table 2. Estimates of K2P genetic distance in Theba pisana CO1 mtDNA within and between sites in California (San Pedro, Los Angeles County and San Elijo Lagoon Ecological Reserve, San Diego County) and elsewhere in the world (see Figure 8C).

\begin{tabular}{lccc}
\hline & $\begin{array}{c}\text { San Pedro } \\
\text { T. pisana }\end{array}$ & $\begin{array}{c}\text { San Elijo } \\
\text { T. pisana }\end{array}$ & $\begin{array}{c}\text { All } \\
\text { T. pisana }\end{array}$ \\
\hline San Pedro T. pisana $(n=17)$ & 0.004 & & \\
San Elijo T. pisana $(n=10)$ & 0.131 & 0.004 & \\
all other T. pisana $(n=128)$ & 0.059 & 0.127 & 0.087 \\
\hline
\end{tabular}




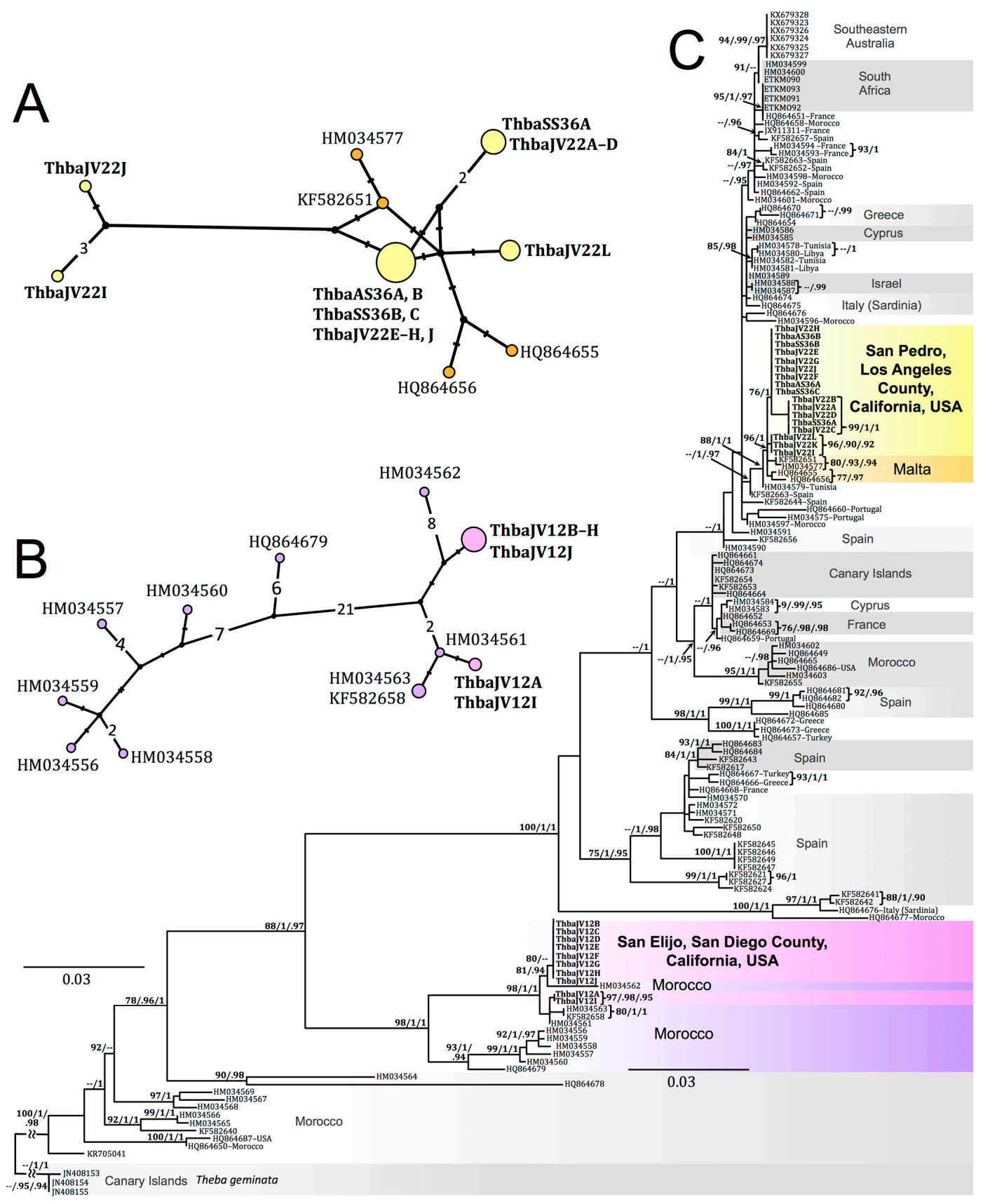

Figure 8. Haplotype networks and RAxML maximum likelihood phylogeny of Theba pisana mtDNA CO1 haplotypes (655 bp) from specimens collected in San Pedro, Los Angeles County and San Elijo Lagoon Ecological Reserve, San Diego County, California and available CO1 barcodes of T. pisana were native and introduced. (A) Median-joining network of 17 T. pisana CO1 haplotypes from specimens collected in San Pedro, Los Angeles County, California (in yellow) and 4 T. pisana CO1 haplotypes from Malta (in orange) [1,39,40]. (B) Median-joining network of 10 T. pisana CO1 haplotypes from specimens collected in San Elijo Lagoon Ecological Reserve, San Diego County, California (in pink) and 10 T. pisana CO1 haplotypes from Morocco (in purple) $[1,39,40]$. In both haplotype networks, circle size is proportional to the number of shared haplotypes in the dataset, and each hashmark represents a single nucleotide difference between haplotypes. (C) RAxML phylogeny based on partial CO1 sequence data (655 bp) from specimens collected in San Pedro, Los Angeles County and San Elijo Lagoon Ecological Reserve, San Diego County, with the outgroup Theba geminata, GenBank acc. no. JN408154, from Lanzarote, Canary Islands, Spain [39]. Color coding is consistent with haplotype networks. RA $\times$ ML bootstrap support values $\geq 75$ are followed by Bayesian posterior probabilities $\geq 0.90$ and Bayesian posterior probabilities for the dataset analyzed without the third codon position. Specimen names and locations in bold indicate T. pisana specimens collected in Southern California and sequenced for this study; GenBank accession numbers are in Table 1. 


\section{Discussion}

\subsection{Theba pisana in Southern California}

Analysis of two molecular markers (CO1 and ITS2) revealed separate lineages of T. pisana in Southern California, indicating at least two introduction events that have resulted in present-day established populations in Los Angeles and San Diego Counties. Mitochondrial CO1 and $16 \mathrm{~S}$ from T. pisana collected at several sites in San Pedro, Los Angeles County, show a single origin, the cause of which is unclear [22]. The spread of T. pisana to noncontiguous sites within San Pedro may have been facilitated unintentionally by humans and is likely to continue given the propensity of T. pisana to aestivate on structures, including vehicles. The similarity of San Pedro CO1 haplotypes to those from Malta could indeed indicate Maltese origin, but not all Mediterranean regions where T. pisana is prolific are represented in available data. CO1 haplotypes of Theba pisana from San Elijo, San Diego County are most similar to specimens from Morocco, and further sampling within San Diego County may reveal additional lineages with the same or different provenance. Morphological differences in jaws and mucous glands between San Pedro and San Elijo populations merit further investigation, as they may be useful in differentiating lineages or identifying cryptic taxa.

These results contribute to a growing body of literature that documents repeated introduction of terrestrial gastropod taxa at sites around the world, e.g., Ambigolimax valentianus (Férussac, 1821) in Japan [68], Arion subfuscus (Draparnaud, 1805) in the U.S. [69,70], Cepaea nemoralis (Linnaeus) in North America [71,72], Cornu aspersum (Müller, 1774) in North and South America [73-75], Deroceras invadens Reise, Hutchinson, Schunack and Schlitt, 2011 in Europe and North America [76], Helix spp. in Europe [77], and Lissachatina fulica (Bowdich, 1822) in South America [78,79]. Such studies also highlight the phenomenon of biotic homogenization [80], identify anthropogenic pathways of introduction [81], may improve protocols for species interception and quarantine, and inform strategies for invasive species eradication or control [81]. Likewise, the distinct parentage of T. pisana in Southern California could be an important component of studies focused on diversification in the genus Theba [82] and varied investigations of genetic drift [83] and the founder effect [84], resource use [85], niche partitioning [86] and adaptation [87-89] in introduced gastropods. We anticipate that the CO1 barcodes and $16 \mathrm{~S}$ and ITS2 sequences from T. pisana specimens generated for this study will be useful in assessing the provenance of new populations and interceptions of T. pisana in California, elsewhere in North America, and worldwide.

The K2P genetic distance between the CO1 barcode fragments of T. pisana from San Pedro and San Elijo is 13\%, which, in many other taxa, would be enough to designate them as separate species [90-92]. However, in the stylommatophora (land snails and slugs), intraspecific $\mathrm{CO} 1$ genetic distance can be as high as 30\% [93], while interspecific genetic distance may be $1-3 \%$ [94,95]. Although a taxonomic treatment of T. pisana, its subspecies, and/or the identification of cryptic taxa are beyond the scope of this study, the preliminary integrative taxonomic work herein may provide a basis on which diversity within T. pisana and its lineages are further investigated [39].

\subsection{Non-Californian Theba pisana}

For T. pisana outside of California, analysis of CO1 barcode haplotypes indicates putative source populations in locations where it is introduced. For example, a monophyletic Southeastern Australian clade was sister to a polytomy of several South African haplotypes indicating a possible South African origin for SE Australian T. pisana, a scenario discussed by Däumer et al. [1]. The presence of France, Morocco, Spain, and the Canary Islands throughout the phylogeny highlights the remarkable diversification of T. pisana within its range and the complex history of its colonization and re-introduction at these localities [1]. Undoubtedly, and as discussed elsewhere [1,39], greater geographic sampling would facilitate determining source populations of T. pisana at other sites where it is introduced. This is particularly relevant for localities with T. pisana populations not represented in this dataset, for example, Argentina [2]. 


\subsection{Mucous Glands}

Mucous gland and jaw morphology were different between sites, with San Elijo (San Diego County) specimens having bi-lobed mucous glands and pronounced jaw ridges, and San Pedro (Los Angeles County) specimens having single-lobed mucous glands and less pronounced jaw ridges. According to several authors, mucous gland size (e.g., small vs. large), thickness (e.g., slender vs. thick) but not lobe morphology (e.g., single vs. bi-lobed) is variable within T. pisana [3,44]. Published drawings of the reproductive system in T. pisana and related lineages and varieties (e.g., T. pisana from Israel, T. andalusica from Spain, T. $p$. almogravensis from Portugal) depict only cylindrical, single-lobed mucous glands $[3,42,44,96]$. Likewise, Hesse [66] illustrates mucous glands as only single-lobed in specimens from Egypt, Lebanon, and Spain, but references bi-lobed mucous glands in T. pisana having been found by the malacologist, Moquin-Tandon, (in German: "Nach Moquin-Tandon sollen die glandulae mucosae zuweilen gespalten sein; mir ist ein solcher Fall nicht vorgekommen"). However, in Moquin-Tandon's treatment of T. pisana (as Helix pisana), only single-lobed mucous glands are illustrated (in his Plate 19, Figure 16) [97].

Confounding efforts to distinguish if mucous gland morphology is lineage or speciesspecific is that reproductive morphology in T. pisana is not well documented throughout ontogeny [3]. Although some authors have indicated that "local forms" of T. pisana may be distinguished based on genitalia [3,96], ontogenetic series of their morphology is lacking. Without an assessment of the reproductive system in T. pisana throughout its maturation, it is unknown if mucous glands develop from bi-lobed to single-lobed or vice versa, though we suspect they do not. In samples analyzed herein, T. pisana collected in June from the White Point Nature Preserve have mostly immature genitalia with single-lobed mucous glands, which remained single lobed by October but had grown in size. Additionally and importantly, what we interpret as intermediate reproductive maturity in San Elijo specimens may actually be mature for that lineage. Therefore, although not explicitly tested, mucous gland morphology may be a lineage-specific trait in T. pisana.

\subsection{Jaw}

The morphology of the single jaw in T. pisana differed between specimens from San Pedro and San Elijo sites in the prominence of ridges, measured as the ratio of jaw ridge length to jaw length. It is not clear if this difference is lineage-specific and taxonomically valuable or an artifact of ontogeny. Both Moquin-Tandon [97] and Hesse [66] illustrate jaw morphology in T. pisana: Moquin-Tandon presents juveniles as having jaws with two ridges, while adults have three (his Plate 19, Figures 9 and 10). Hesse [66] characterized the jaw as having 2-4 ridges, and of 56 specimens he examined, $66 \%$ had two ridges, and most of the remaining had three. Hesse also found that in a sample of 40 putative juveniles with shell sizes from 6-14 mm: 26 jaws had two ridges, 13 had three ridges, and one had four ridges [66]. Despite the detail of Hesse's observations, it is unclear if variation in jaw ridge number is a consequence of ontogeny or varies among same-aged T. pisana individuals within a lineage. Notably, Moran [42] found that a proportion of T. pisana within populations in Israel retained immature genitalia despite being of adult age; it is unknown if jaw ridge number varied in these developmentally arrested snails. In our small sample, the largest jaws from the most developmentally mature T. pisana collected in San Pedro (from October 2020, Figure 6D,I) had two prominent jaw ridges, which contradicts MoquinTandon [97] and may indicate that jaw ridge number is unrelated to ontogeny. Additionally, our finding that jaw ridges (regardless of number) were more prominent and in greater relief in San Elijo T. pisana than in those from San Pedro may indicate a lineage-specific trait that merits further investigation.

\subsection{Shell and Radula}

Highly variable banding patterns and shell pigmentation in T. pisana were observed herein but not analyzed between or within sites. For a detailed treatment and discussion of shell banding, see Cain [98], Cowie [99], and Köhler et al. [89]. Radular morphology 
was consistent with illustrations and descriptions by other authors $[66,67]$ and was not significantly different between T. pisana from Los Angeles and San Diego sites.

\subsection{Pathway(s) of Introduction into California}

The means by which T. pisana was introduced to Southern California are uncertain, though many pathways are possible. Theba pisana has been regularly intercepted in imports since the 1930s at ports in the U.S., in cargo destined for California, and in goods coming through Southern California ports (e.g., Los Angeles, Long Beach, San Diego). From the 1930s-1980s, imported goods documented to contain T. pisana individuals include hyacinth bulbs, lilies and other flowers, endive, broad bean, rosemary, sand, soil, hides, tile, wood, and straw [100-105]. Theba pisana has also been recovered living in military cargo, automobiles, and baggage mostly from circum-Mediterranean countries [100]. Two T. pisana individuals intercepted separately in imported goods in Minnesota, USA, and included in the phylogeny by Däumer et al. [1] (GenBank acc. nos. HQ864686 and HQ864687) appear to both be of Moroccan origin, though not closely related. Therefore, a Maltese and/or Moroccan lineage of T. pisana in Southern California could have been due to snails from a variety of imports, making its introduction potentially human-mediated and inadvertent.

However, local narratives in Southern California posit that T. pisana was first introduced intentionally to La Jolla, San Diego County from Italy, or specifically, Sicily $[12,13]$. The importer, as the story goes, was a La Jolla resident and/or Italian immigrant who intended to raise the snails for eating and/or selling, but the snails escaped or were discarded and then proliferated [20,22]. Indeed, T. pisana is common in Italy [106] and is eaten especially in Sicily [107], where it is prepared as 'Lumache siciliane' (Italian for 'snails Sicilian') or 'Babbaluci alla palermitana' (Sicilian for 'snails Palermo style') and is particularly popular during the summer feast of Santa Rosalia $[108,109]$. Because we did not include La Jolla-collected specimens in this study, we cannot directly test the plausibility of this narrative, assuming that T. pisana from La Jolla in the 1920s survived attempts at eradication. Additionally and importantly, our dataset does not include specimens from Sicily or mainland Italy, making the ability to test this Italian-origin hypothesis untenable even if we had T. pisana from La Jolla. The only Italian CO1 haplotypes in our dataset are from the island of Sardinia [1] (GenBank acc. nos. HQ864674-76) and these do not cluster with San Pedro or San Elijo CO1 haplotypes. Therefore, although San Elijo T. pisana, which is the only San Diego County-collected population in our dataset, has Moroccan parentage based on our analyses, we cannot reject a potential Italian origin for T. pisana elsewhere in San Diego County.

Regarding the Moroccan affinity of San Elijo T. pisana: it is possible that the present-day population we sampled descended from snails brought to northern San Diego County from Morocco for culinary purposes, as T. pisana is sometimes used in Moroccan preparations of Marrakech snail soup, known in Arabic as 'babbouche' [110]. However, this may not be a particularly likely scenario because babbouche is traditionally prepared with land snails in the genus Otala. It is also possible that T. pisana was intentionally introduced from elsewhere in the Mediterranean where it is eaten, e.g., Andalusia, Spain, where it is prepared as "caracoles chicos en caldo" (Spanish for 'small snails in broth'), and that T. pisana from Spain and Morocco share haplotypes not present in our dataset. Speculations notwithstanding, the human-mediated pathway of introduction for San Elijo T. pisana remains unresolved.

All three molecular loci (mitochondrial CO1, 16S, and nuclear ITS2) analyzed from San Pedro, Los Angeles-collected T. pisana indicate a single common origin. These San Pedro sequences were most closely related to each other and were most similar to specimens collected on the Mediterranean island of Malta in the CO1 haplotype. We do not know if previously established populations of T. pisana in San Pedro, e.g., the 1935 populations that were supposedly eradicated [29], had a different parental origin or if some individuals survived and are the ancestors of the populations sampled in 2019 and 2020 for this study. 
Unfortunately, the malacology collections of NHMLAC do not include specimens from these 1935 populations or the Manhattan Beach population of the 1960s. While whole snail specimens collected from the 1930s-1960s could have been preserved in formalin, making DNA extraction potentially difficult, the morphology of jaws and reproductive parts would have been well preserved and could have been compared to living populations. Therefore, we reiterate recent appeals from several authors $[111,112]$ to collect introduced species from urban and developed environments and make them available for study in museum collections.

In San Pedro, the maritime community of the early 20th century comprised a sizable Italian immigrant population from the islands of Ischia and Sicily [113,114]. Today, this population constitutes the largest Italian-American enclave in Los Angeles County [115]. It is possible that the T. pisana populations that proliferated in southeastern San Pedro in the 1930s were a consequence of Italian immigrants bringing this snail to the region as an edible delicacy, similar to the origin story of La Jolla T. pisana in the 1920s. In our dataset, the closest locality to Sicily from which we have CO1 haplotypes is Malta. Without Sicilian T. pisana haplotypes for comparison, we do not know if Maltese and Sicilian T. pisana share haplotype(s) that could indicate a possible Sicilian origin for present-day San Pedro snails that were not eradicated in the 1930s. Of course, and in addition to other alternative scenarios, T. pisana could have been introduced intentionally or accidentally to San Pedro from Malta after the eradication of the 1930s T. pisana infestation.

\section{Conclusions}

The establishment of two genetically divergent T. pisana lineages in Southern California indicates this species' diversity and success were nonnative. Although its pathways of introduction into Los Angeles and San Diego Counties are not clear, the provenance of these lineages may be elucidated by greater sampling of T. pisana throughout Italy and in other regions where it is common but not represented in our dataset. Likewise, greater sampling throughout Southern California, especially within San Diego County, may reveal additional introduction events. The observation that the jaw and mucous gland morphology in T. pisana were distinct between Los Angeles and San Diego populations could inform future systematic treatments of T. pisana and merits further investigation. With the knowledge that multiple T. pisana lineages have proliferated in Southern California, subsequent studies could assess associated phenomena, such as introgression, niche partitioning, adaptation, and could inform efforts for species control.

Supplementary Materials: The following are available online at https:/ /www.mdpi.com/article/10 .3390/insects12080662/s1, Figure S1: Close-up of Figure 8.

Author Contributions: Conceptualization, J.E.V.; methodology, J.E.V., K.S., A.S., and A.G.; analysis, J.E.V., K.S., A.S., and A.G.; research, J.E.V., K.S., A.S., and A.G.; figure preparation, J.E.V.; writingoriginal draft preparation, J.E.V.; writing-review and editing, K.S., A.S., and A.G.; supervision, J.E.V.; project administration, J.E.V.; funding acquisition, J.E.V. All authors have read and agreed to the published version of the manuscript.

Funding: This research was funded by the Glendale College Foundation of Glendale Community College, Glendale, California.

Institutional Review Board Statement: Not applicable.

Data Availability Statement: Phylogenies may be found at TreeBase: http://purl.org/phylo/ treebase/phylows/study/TB2:S28531 (accessed on 13 April 2021).

Acknowledgments: The authors would like to thank Rory Mc Donnell of Oregon State University for helpful discussions; Armelle Ansart-Geslin of the French National Centre for Scientific Research for specimen locality information; David Tran for German translation assistance; Shahane Simonyan for research contributions; Brian Brown, Lisa Gonzalez, and Ariel DeLa Cruz (WPNP) for providing T. pisana specimens from BioSCAN insect traps; Estella Hernandez for laboratory management; Greg Pauly for collected specimens; Lindsey Groves for specimen processing and databasing; Maiz 
Connolly for photos; Betty L. Uyeda for help with newspaper research, Trevor Alixopulos and Susan Eubank (Los Angeles Arboretum) for access to literature, and three anonymous reviewers for their thoughtful comments and thorough edits. Special thanks are owed to the members of the NHMLAC Urban Nature Research Center (UNRC) team for conversations about this project and valuable comments on drafts of this manuscript. We are also grateful to the White Point Nature Preserve, Palos Verdes Peninsula Land Conservancy, San Elijo Lagoon Ecological Reserve, Nature Collective, and the County of San Diego Parks and Recreation. Our thanks as well to the Biodiversity Heritage Library (www.biodiversitylibrary.org) for access (December 2020-June 2021) to several works that would otherwise have gone unexamined. Finally, we express our gratitude to Glendale Community College, Glendale, California, for permitting the Biology 50 internship course to continue throughout the coronavirus pandemic and to the Glendale College Foundation, which provided the generous funding that made this study possible.

Conflicts of Interest: The authors declare no conflict of interest. The funders had no role in the design of the study; in the collection, analyses, or interpretation of data; in the writing of the manscript, or in the decision to publish the results.

\section{References}

1. Däumer, C.; Greve, C.; Hutterer, R.; Misof, B.; Haase, M. Phylogeography of an invasive land snail: Natural range expansion versus anthropogenic dispersal in Theba pisana pisana. Biol. Invasions 2012, 14, 1665-1682. [CrossRef]

2. Rumi, A.; Sánchez, J.; Ferrando, N.S. Theba pisana (Müller, 1774) (Gastropoda, Helicidae) and other alien land molluscs species in Argentina. Biol. Invasions 2010, 12, 2985-2990. [CrossRef]

3. Gittenberger, E.; Ripken, T.E. The genus Theba (Mollusca: Gastropoda: Helicidae), systematics and distribution. Zool. Verh. Leiden 1987, 241, 1-62.

4. Odendaal, L.J.; Haupt, T.M.; Griffiths, C.L. The alien invasive land snail Theba pisana in the West Coast National Park: Is there cause for concern? Koedoe 2008, 50, 93-98. [CrossRef]

5. Herbert, D.G. The Introduced Terrestrial Mollusca of South Africa; South African National Biodiversity Institute, SANBI Biodiversity Series: Pretoria, South Africa, 2010; pp. 1-108. Available online: http://opus.sanbi.org/bitstream/20.500.12143/5678/1/ BioSeries_15_2010.pdf (accessed on 24 April 2020).

6. Roth, B.; Hertz, C.M.; Cerutti, R. White snails (Helicidae) in San Diego County, California. Festivus 1987, 19, 84-88.

7. Baker, G.H.; Vogelzang, B.K. Life history, population dynamics and polymorphism of Theba pisana (Mollusca: Helicidae) in Australia. J. Appl. Ecol. 1988, 25, 867-887. [CrossRef]

8. Baker, G.H. The population dynamics of the Mediterranean snails Cernuella virgata, Cochlicella acuta (Hygromiidae) and Theba pisana (Helicidae) in pasture-cereal rotations in South Australia: A 20-year study. Aust. J. Exp. Agric. 2008, 48, 1514-1522. [CrossRef]

9. Cooperative Economic Insect Report (CEIR). Animal and Plant Health Inspection Service. In Plant Protection and Quarantine Programs; CEIR: Washington, DC, USA, 1966; Volume 16, p. 205.

10. Hanna, G. Introduced molluscs of western North America. Occas. Pap. Calif. Acad. Sci. 1966, 48, 1-108.

11. Cowie, R.; Robinson, D.G. Pathways of introduction of nonindigenous land and freshwater snails and slugs. In Invasive Species: Vectors and Management Strategies; Carlton, J., Ed.; Island Press: Washington, DC, USA, 2003; p. 30.

12. Daily Wire AP. Snails Menace All Vegetation at La Jolla. The San Francisco Call, 5 May 1922; 111.

13. Daily Wire AP. Snails Worry at La Jolla. Los Angeles Times, 6 May 1922.

14. Dean, J.D. Land mollusca in the Vale of Glamorgan. Cardiff Nat. Soc. Rep. Trans. 1915, 48, 50-58.

15. Hodel, R.; Arakelian, G.; Wilen, C. The White Garden Snail. An old but potentially series pest of landscape ornamentals. PalmArbor 2018, 3, 1-20.

16. Tandingan De Ley, I.; Schurkman, J.; Wilen, C.; Dillman, A.R. Mortality of the invasive white garden snail Theba pisana exposed to three US isolates of Phasmarhabditis spp. (P. hermaphrodita, P. californica, and P. papillosa). PLoS ONE 2020, 15, e0228244. [CrossRef]

17. Basinger, A.J. The White Snail (Helix pisana) at La Jolla, California. J. Econ. Entomol. 1923, 16, 522-526. [CrossRef]

18. Cockerell, T.D.A. Helix pisana in California. Am. Nat. 1924, 58, 190-192. [CrossRef]

19. Gammon, E.T. Helicid snails in California. Bull. Calif. Dep. Agric. 1943, 32, 173-187.

20. Snail Cleanup at La Jolla. Bl. Trib. 1922, 33, 1.

21. Mishler, M. Archivist Notes. Timekeeper Newsl. Jolla Hist. Soc. 2012, 21, 6.

22. Daily Wire AP. Snails Menace La Jolla's Gardens. La Jolla Journal, 28 April 1922.

23. White Snail Fight on at San Diego. Los Angeles Times, 6 August 1924.

24. Miller, E.; Swails, S.; Swails, D.; Olson, F.; Staen, R.T. White garden snail (Theba pisana Müller) Efficacy of selected bait and sprayable molluscicides. J. Agric. Entomol. 1988, 5, 189-197.

25. Norris, M. Pests last seen in 1922: Destructive White Snails Back in Country. Los Angeles Times, 17 August 1985; p. A3.

26. Hanna, G.D. A new outbreak of Helix pisana in California. Nautilus 1933, 46, 139-140.

27. Pilsbry, H. Land Mollusca of North America (north of Mexico). Acad. Nat. Sci. Phila. Mono. 1939, 3, 1-573. 
28. Basinger, A.J. Measuring the Efficiency of Materials Used for Snail Control. J. Econ. Entomol. 1935, 28, 903-905. [CrossRef]

29. War on Pests Calls for Heroic Campaign. Los Angeles Times, 17 June 1935; p. A8.

30. Cooperative Economic Insect Report (CEIR). Animal and Plant Health Inspection Service. Plant Protection and Quarantine Programs; CEIR: Washington, DC, USA, 1968; Volume 18.

31. Cooperative Economic Insect Report (CEIR). Animal and Plant Health Inspection Service. Plant Protection and Quarantine Programs; CEIR: Washington, DC, USA, 1971; Volume 21.

32. Dees, L.T. Edible land snails in the United States; US Department of the Interior, Fish and Wildlife Service, Bureau of Sport Fisheries and Wildlife: U.S. Government Printing Office: Washington, DC, USA, 1970; Volume 91, p. 8.

33. Smart, R. Theba pisana Observation; iNaturalist: San Pedro, CA, USA, 2013. Available online: https://www.inaturalist.org/ observations / 274431 (accessed on 24 April 2021).

34. NatureinLA. Theba pisana Observation; iNaturalist: San Pedro, CA, USA, 2015. Available online: https://www.inaturalist.org/ observations /1769498 (accessed on 24 April 2021).

35. Littlejohn, D. Snails Run Amok: San Pedro Nature Preserve Reluctant Host to Invasive Creatures. Daily Breeze, 26 July 2019. Available online: https: / / www.dailybreeze.com/2019/07/26/snails-run-amok-san-pedro-nature-preserve-reluctant-host-toinvasive-creatures / (accessed on 12 March 2021).

36. Cowie, R.H.; Dillon, R.T.; Robinson, D.G.; Smith, J.W. Alien non-marine snails and slugs of priority quarantine importance in the United States: A preliminary risk assessment. Am. Malacol. Bull. 2009, 27, 113-132. [CrossRef]

37. Cowie, R.H. Microhabitat choice and high temperature tolerance in the land snail Theba pisana (Mollusca: Gastropoda). J. Zool. 1985, 207, 201-211. [CrossRef]

38. Johnson, M.S. Founder effects and geographic variation in the land snail Theba pisana. Heredity 1988, 61, 133-142. [CrossRef]

39. Greve, C.; Hutterer, R.; Groh, K.; Haase, M.; Misof, B. Evolutionary diversification of the genus Theba (Gastropoda: Helicidae) in space and time: A land snail conquering islands and continents. Mol. Phylogenetics Evol. 2010, 57, 572-584. [CrossRef]

40. Haase, M.; Greve, C.; Hutterer, R.; Misof, B. Amplified fragment length polymorphisms, the evolution of the land snail genus Theba (Stylommatophora: Helicidae), and an objective approach for relating fossils to internal nodes of a phylogenetic tree using geometric morphometrics. Zool. J. Linn. Soc. 2014, 171, 92-107. [CrossRef]

41. Brown, B.; Borkent, A.; Wetzer, R.; Pentcheff, D. New types of inventories at the Natural History Museum of Los Angeles County. Am. Entomol. 2014, 60, 231-232. [CrossRef]

42. Moran, S. Weather-and population density-induced infantilism in the landsnail Theba pisana in a semi-arid climate. Int. J. Biometeorol. 1989, 33, 101-108. [CrossRef]

43. Koene, J.M.; Schulenburg, H. Shooting darts: Co-evolution and counter-adaptation in hermaphroditic snails. BMC Evol. Biol. 2005, 5, 25. [CrossRef] [PubMed]

44. Holyoak, D.T.; Holyoak, G.A. Reassessment of the keeled subspecies of Theba pisana (Gastropoda: Helicidae) from the sand dunes of south-western Portugal. Iberus 2016, 34, 19-39.

45. Folmer, O.; Black, M.; Hoeh, W.; Lutz, R.; Vrijenhoek, R. DNA primers for amplification of mitochondrial cytochrome $c$ oxidase subunit I from diverse metazoan invertebrates. Mol. Mar. Biol. Biotechnol. 1994, 3, 294-299. [PubMed]

46. Geller, J.; Meyer, C.; Parker, M.; Hawk, H. Redesign of PCR primers for mitochondrial cytochrome c oxidase subunit I for marine invertebrates and application in all-taxa biotic surveys. Mol. Ecol. Resour. 2013, 13, 851-861. [CrossRef] [PubMed]

47. Palumbi, S.R. Nucleic acids II: The polymerase chain reaction. In Molecular Systematics; Hillis, D.M., Moritz, C., Mable, B.K., Eds.; Sinauer \& Associates Inc.: Sunderland, MA, USA, 1996; pp. 205-247.

48. Wade, C.M.; Mordan, P.B. Evolution within the gastropod molluscs; using the ribosomal RNA gene-cluster as an indicator of phylogenetic relationships. J. Molluscan Stud. 2000, 66, 565-570. [CrossRef]

49. Vendetti, J.; Burnett, E.; Carlton, L.; Curran, A.T.; Lee, C.; Matsumoto, R.; Mc Donnell, R.; Reich, I.; Willadsen, O. The introduced terrestrial slugs Ambigolimax nyctelius (Bourguignat, 1861) and Ambigolimax valentianus (Férussac, 1821) (Gastropoda: Limacidae) in California, with a discussion of taxonomy, systematics, and discovery by citizen science. J. Nat. Hist. 2019, 53, 1607-1632. [CrossRef]

50. Kearse, M.; Moir, R.; Wilson, A.; Stones-Havas, S.; Cheung, M.; Sturrock, S.; Buxton, S.; Cooper, A.; Markowitz, S.; Duran, C.; et al Geneious Basic: An integrated and extendable desktop software platform for the organization and analysis of sequence data. Bioinformatics 2012, 28, 1647-1649. [CrossRef] [PubMed]

51. Böckers, A.; Greve, C.; Hutterer, R.; Misof, B.; Haase, M. Testing heterogeneous base composition as potential cause for conflicting phylogenetic signal between mitochondrial and nuclear DNA in the land snail genus Theba Risso 1826 (Gastropoda: Stylommatophora: Helicoidea). Org. Divers. Evol. 2016, 16, 835-846. [CrossRef]

52. Villesen, P. FaBox: An online toolbox for fasta sequences. Mol. Ecol. Notes 2007, 7, 965-968. [CrossRef]

53. Kumar, S.; Stecher, G.; Tamura, K. MEGA7: Molecular evolutionary genetics analysis version 7.0 for bigger datasets. Mol. Biol. Evo. 2016, 33, 1870-1874. [CrossRef] [PubMed]

54. Darriba, D.; Taboada, G.; Doallo, R.; Posada, D. jModelTest 2: More models, new heuristics and parallel computing. Nat. Methods 2012, 9, 772. [CrossRef]

55. Darriba, D.; Posada, D.; Kozlov, A.M.; Stamatakis, A.; Morel, B.; Flouri, T. ModelTest-NG: A new and scalable tool for the selection of DNA and protein evolutionary models. Mol. Biol. Evo. 2020, 37, 291-294. [CrossRef] 
56. Miller, M.; Pfeiffer, W.; Schwartz, T. Creating the CIPRES Science Gateway for inference of large phylogenetic trees. In Proceedings of the Gateway Computing Environments Workshop (GCE), New Orleans, LA, USA, 14 November 2010; pp. 1-8.

57. Bouaziz-Yahiatene, H.; Pfarrer, B.; Medjdoub-Bensaad, F.; Neubert, E. Revision of Massylaea Möllendorff, 1898 (Stylommatophora, Helicidae). ZooKeys 2017, 694, 109-133. [CrossRef]

58. Razkin, O.; Gómez-Moliner, B.J.; Prieto, C.E.; Martínez-Ortí, A.; Arrébola, J.R.; Muñoz, B.; Chueca, L.J.; Madeira, M.J. Molecular phylogeny of the western Palaearctic Helicoidea (Gastropoda, Stylommatophora). Mol. Phylogenet. Evol. 2015, 83, 99-117. [CrossRef]

59. Neiber, M.; Hausdorf, B. Molecular phylogeny reveals the polyphyly of the snail genus Cepaea (Gastropoda: Helicidae). Mol. Phylogenetics Evol. 2015, 93, 143-149. [CrossRef]

60. Bandelt, H.; Forster, P.; Röhl, A. Median-joining networks for inferring intraspecific phylogenies. Mol. Biol. Evol. 1999, 16, 37-48. [CrossRef]

61. Leigh, J.W.; Bryant, D. Popart: Full-feature software for haplotype network construction. Methods Ecol. Evol. 2015, 6, 1110-1116. [CrossRef]

62. Stamatakis, A. RAxML version 8: A tool for phylogenetic analysis and post-analysis of large phylogenies. Bioinformatics 2014, 30, 1312-1313. [CrossRef]

63. Ronquist, F; Huelsenbeck, J. MrBayes 3: Bayesian phylogenetic inference under mixed models. Bioinformatics 2003, 19, 1572-1574. [CrossRef] [PubMed]

64. Pattengale, N.D.; Alipour, M.; Bininda-Emonds, O.R.; Moret, B.M.; Stamatakis, A. How many bootstrap replicates are necessary? J. Comput. Biol. 2010, 17, 337-354. [CrossRef] [PubMed]

65. Rambaut, A. FigTree v1. 3.1. 2009. Available online: http://tree.bio.ed.ac.uk/software/figtree/ (accessed on 12 March 2021).

66. Hesse, P. Genus Euparypha Hartm. In Iconographie der Land- E Süsswasser-Mollusken mit Vorzüglicher Berücksichtigung der Europäischen Noch Nicht Abgebildeten Arten; Band, N.F., Ed.; Berlin \& Wiesbaden: Wiesbaden, Germany, 1915; pp. 1-72, [In German]. Available online: http:/ / biodiversitylibrary.org/page/280865 (accessed on 13 March 2020).

67. Barker, G.M.; Efford, M.G. Predatory Gastropods as Natural Enemies of Terrestrial Gastropods and Other Invertebrates. In Natural Enemies of Terrestrial Molluscs; CABI Publishing: Wallingford, UK, 2004; pp. 279-403.

68. Satoh, S.S.; Ikeda, S.; Yamazaki, Y. Multiple introduction events and artificial long-distance dispersal of the exotic slug Ambigolimax valentianus in Japan. Molluscan Res. 2020, 40, 276-281. [CrossRef]

69. Pinceel, J.; Jordaens, K.; Van Houtte, N.; Bernon, G.; Backeljau, T. Population genetics and identity of an introduced terrestrial slug: Arion subfuscus sl in the north-east USA (Gastropoda, Pulmonata, Arionidae). Genetica 2005, 125, 155-171. [CrossRef]

70. Mc Donnell, R.J.; Rugman-Jones, P.; Backeljau, T.; Breugelmans, K.; Jordaens, K.; Stouthamer, R.; Paine, T.; Gormally, M. Molecular identification of the exotic slug Arion subfuscus sensu stricto (Gastropoda: Pulmonata) in California, with comments on the source location of introduced populations. Biol. Invasions 2011, 13, 61-66. [CrossRef]

71. Grindon, A.J.; Davison, A. Irish Cepaea nemoralis land snails have a cryptic Franco-Iberian origin that is most easily explained by the movements of Mesolithic humans. PLoS ONE 2013, 8, e65792. [CrossRef] [PubMed]

72. Layton, K.K.; Warne, C.P.K.; Nicolai, A.; Ansart, A.; deWaard, J.R. Molecular evidence for multiple introductions of the banded grove snail (Cepaea nemoralis) in North America. Can. J. Zool. 2019, 97, 392-398. [CrossRef]

73. Guiller, A.; Martin, M.C.; Hiraux, C.; Madec, L. Tracing the invasion of the Mediterranean land snail Cornu aspersum aspersum becoming an agricultural and garden pest in areas recently introduced. PLoS ONE 2012, 7, e49674. [CrossRef]

74. Gaitán-Espitia, J.D.; Scheihing, R.; Poulin, E.; Artacho, P.; Nespolo, R.F. Mitochondrial phylogeography of the land snail Cornu aspersum: Tracing population history and the impact of human-mediated invasion in austral South America. Evol. Ecol. Res. 2013, $15,61-78$.

75. Sherpa, S.; Ansart, A.; Madec, L.; Martin, M.C.; Dréano, S.; Guiller, A. Refining the biogeographical scenario of the land snail Cornu aspersum aspersum: Natural spatial expansion and human-mediated dispersal in the Mediterranean basin. Mol. Phylogenetics Evol. 2018, 120, 218-232. [CrossRef] [PubMed]

76. Hutchinson, J.; Schlitt, B.; Kořínková, T.; Reise, H.; Barker, G.M. Genetic evidence illuminates the origin and global spread of the slug Deroceras invadens. J. Molluscan Stud. 2020, 86, 306-322. [CrossRef]

77. Korábek, O.; Kosová, T.; Dolejš, P.; Petrusek, A.; Neubert, E.; Juřičková, L. Geographic isolation and human-assisted dispersal in land snails: A Mediterranean story of Helix borealis and its relatives (Gastropoda: Stylommatophora: Helicidae). Zool. J. Linn. Soc. 2021, 26, zlaa186. [CrossRef]

78. Fontanilla, I.K.C.; Maria, I.M.P.S.; Garcia, J.R.M.; Ghate, H.; Naggs, F.; Wade, C.M. Restricted genetic variation in populations of Achatina (Lissachatina) fulica outside of East Africa and the Indian Ocean Islands points to the Indian Ocean Islands as the earliest known common source. PLoS ONE 2014, 9, e105151. [CrossRef]

79. Ayyagari, V.S.; Sreerama, K. Evaluation of haplotype diversity of Achatina fulica (Lissachatina) [Bowdich] from Indian sub-continent by means of $16 \mathrm{~S}$ rDNA sequence and its phylogenetic relationships with other global populations. 3 Biotech 2017, 7, 252. [CrossRef]

80. Capinha, C.; Essl, F.; Seebens, H.; Moser, D.; Pereira, H.M. The dispersal of alien species redefines biogeography in the Anthropocene. Science 2015, 348, 1248-1251. [CrossRef]

81. Ruiz, G.; Carlton, J. Invasion vectors: A conceptual framework for management. In Invasive Species: Vectors and Management Strategies; Carlton, J., Ruiz, G., Eds.; Island Press: Washington, DC, USA, 2003; pp. 459-504. 
82. Greve, C.; Haase, M.; Hutterer, R.; Rödder, D.; Ihlow, F.; Misof, B. Snails in the desert: Species diversification of Theba (Gastropoda: Helicidae) along the Atlantic coast of NW Africa. Ecol. Evol. 2017, 7, 5524-5538. [CrossRef]

83. Yang, Q.Q.; Liu, S.W.; He, C.; Yu, X.P. Distribution and the origin of invasive apple snails, Pomacea canaliculata and P. maculata (Gastropoda: Ampullariidae) in China. Sci. Rep. 2018, 8, 1185. [CrossRef]

84. Xue, D.X.; Graves, J.; Carranza, A.; Sylantyev, S.; Snigirov, S.; Zhang, T.; Liu, J.X. Successful worldwide invasion of the veined rapa whelk, Rapana venosa, despite a dramatic genetic bottleneck. Biol. Invasions 2018, 20, 3297-3314. [CrossRef]

85. Van Elden, S.; Miranda, N.A.; Perissinotto, R.; Adams, J.B. Plant selection and grazing activity of the invasive snail Theba pisana in coastal Algoa Bay, South Africa. Afr. Zool. 2015, 50, 227-231. [CrossRef]

86. Shik, J.Z.; Dussutour, A. Nutritional dimensions of invasive success. Trends Ecol. Evol. 2020, 35, 691-703. [CrossRef]

87. Ożgo, M.; Bogucki, Z. Colonization, stability, and adaptation in a transplant experiment of the polymorphic land snail Cepaea nemoralis (Gastropoda: Pulmonata) at the edge of its geographical range. Biol. J. Linn. Soc. Lond. 2011, 104, 462-470. [CrossRef]

88. Liu, C.; Zhang, Y.; Ren, Y.; Wang, H.; Li, S.; Jiang, F.; Yin, L.; Qiao, X.; Zhang, G.; Qian, W.; et al. The genome of the golden apple snail Pomacea canaliculata provides insight into stress tolerance and invasive adaptation. Gigascience 2018, 7, giy101. [CrossRef]

89. Köhler, H.R.; Capowiez, Y.; Mazzia, C.; Eckstein, H.; Kaczmarek, N.; Bilton, M.C.; Burmester, J.K.; Capowiez, L.; Chueca, L.J.; Favilli, L.; et al. Experimental simulation of environmental warming selects against pigmented morphs of land snails. Ecol. Evol. 2021, 11, 1111-1130. [CrossRef] [PubMed]

90. Hebert, P.D.; Ratnasingham, S.; De Waard, J.R. Barcoding animal life: Cytochrome c oxidase subunit 1 divergences among closely related species. Proc. Royal Soc. B 2003, 270, S96-S99. [CrossRef]

91. Wall-Palmer, D.; Hegmann, M.; Goetze, E.; Peijnenburg, K.T. Resolving species boundaries in the Atlanta brunnea species group (Gastropoda, Pterotracheoidea). ZooKeys 2019, 899, 59-84. [CrossRef]

92. Bodon, M.; Cianfanelli, S.; Chueca, L.J.; Pfenninger, M. Candidula conglomeratica sp. nov. from the northern Apennines, Italy (Gastropoda: Eupulmonata: Geomitridae). Arch. Molluskenkd. 2020, 149, 203-220. [CrossRef]

93. Prevot, V.; Jordaens, K.; Sonet, G.; Backeljau, T. Exploring species level taxonomy and species delimitation methods in the facultatively self-fertilizing land snail genus Rumina (Gastropoda: Pulmonata). PLoS ONE 2013, 8, e60736. [CrossRef]

94. Breugelmans, K.; Jordaens, K.; Adriaens, E.; Remon, J.P.; Cardona, J.Q.; Backeljau, T. DNA barcodes and phylogenetic affinities of the terrestrial slugs Arion gilvus and A. ponsi (Gastropoda, Pulmonata, Arionidae). ZooKeys 2013, 365, 83-104.

95. Davison, A.; Blackie, R.L.; Scothern, G.P. DNA barcoding of stylommatophoran land snails: A test of existing sequences. Mol. Ecol. Resour. 2009, 9, 1092-1101. [CrossRef] [PubMed]

96. Schmidt, A. Der geschlechtsapparat der Stylommatophoren in taxonomischer hinsicht. In Abhandlungen des Naturwissenschaftlichen Vereins für Sachsen und Thüringen in Halle; 1855; Volume 1, pp. 1-52. Available online: https://www.biodiversitylibrary.org/ bibliography/11495 (accessed on 13 April 2021).

97. Moquin-Tandon, A. Histoire Naturelle des Mollusques terrestres et Fluviatiles de France, Contenant des Études Générales Sur Leur Anatomie et Leur Physiologie et la Description Particulière des Genres, des Espèces et des Varieties; Baillière, J.-B., Ed.; Paris, France, 1855; Volume 2. Available online: https:/ / www.biodiversitylibrary.org/item/100085\#page/42/mode/1up (accessed on 13 April 2021).

98. Cain, A.J. Genetics of some morphs in the land snail Theba pisana. Malacologia 1984, 25, 381-411.

99. Cowie, R.H. The life-cycle and productivity of the land snail Theba pisana (Mollusca: Helicidae). J. Anim. Ecol. 1984, 53, 311-325. [CrossRef]

100. List of Intercepted Plant Pests; USDA, Plant Quarantine and Control Administration: Hayattsville, MD, USA, 1931.

101. List of Intercepted Plant Pests; USDA, Plant Quarantine and Control Administration: Hayattsville, MD, USA, 1948.

102. List of Intercepted Plant Pests; USDA, Plant Quarantine and Control Administration: Hayattsville, MD, USA, 1960.

103. List of Intercepted Plant Pests; USDA, Plant Quarantine and Control Administration: Hayattsville, MD, USA, 1982.

104. List of Intercepted Plant Pests; USDA, Plant Quarantine and Control Administration: Hayattsville, MD, USA, 1987.

105. Cooperative Economic Insect Report. US. APHIS; Plant Pest Control Division: Hayattsville, MD, USA, 1987 ; Volume 10.

106. Philippi, R. Enumeratio molluscorum Siciliae cum viventium tum in tellure tertiaria fossilium quae in itinere suo observavit. Berolini, S. Schroppii. 1844, Volume 2, p. 303. Available online: https://www.biodiversitylibrary.org/item/180011\#page/7/ mode/1up (accessed on 14 April 2021).

107. Une société de naturalistes, and d'agriculteurs. Nouveau Dictionnaire d'histoire Naturelle: Appliquée aux arts, à l'Agriculture, à L'économie Rurale et Domestique, à la Médecine, etc; Chez Deterville: Paris, France, 1818; Volume 22, p. 618. Available online: https:/ / www.biodiversitylibrary.org/item/60124\#page/7/mode/1up (accessed on 1 May 2021).

108. Editorial Staff. Palermitani orfani del Festino, ma il 14 luglio non sarà senza "babbaluci". [it Italian]. Sapori di Sicilia Magazine, 12 July 2020. Available online: https:/ / www.saporidisiciliamagazine.it/(accessed on 11 March 2021).

109. Ditta, D. Dalla "calia" ai "babbaluci", senza scordare lo sfincione: La mappa del cibo al Festino. [it Italian]. Palermo Today, 13 July 2018. Available online: https://www.palermotoday.it/attualita/mappa-cibo-festino-santa-rosalia-2018.html(accessed on 11 March 2021).

110. Wolfert, P. The Food of Morocco; A\&C Black: London, UK, 2012; p. 528.

111. Meineke, E.K.; Davies, T.J.; Daru, B.H.; Davis, C.C. Biological collections for understanding biodiversity in the Anthropocene. Philos. Trans. R. Soc. B. 2018, 374, 20170386. [CrossRef] [PubMed]

112. Shultz, A.J.; Adams, B.J.; Bell, K.C.; Ludt, W.B.; Pauly, G.B.; Vendetti, J.E. Natural history collections are critical resources for contemporary and future studies of urban evolution. Evol. Appl. 2021, 14, 233-247. [CrossRef] 
113. Lothrop, G. Italians of Los Angeles: An Historical Overview. South. Calif. Q. 2003, 85, 249-300. [CrossRef]

114. Gatto, M. Los Angeles's Little Italy; Arcadia Publishing: San Francisco, CA, USA, 2009; p. 128.

115. Littlejohn, D. Little Italy district coming to San Pedro, dividing public opinion. Daily Breeze, 27 September 2019. Available online: https:/ / www.dailybreeze.com/2019/09/27/little-italy-district-coming-to-san-pedro-dividing-public-opinion/ (accessed on 12 March 2021) 